\title{
Paleoeskimo Demography and Sea-Level History, Kent Peninsula and King William Island, Central Northwest Passage, Arctic Canada
}

\author{
ARTHUR S. DYKEㄹ and JAMES M. SAVELLE ${ }^{2}$
}

(Received 10 April 2008; accepted in revised form 22 December 2008)

\begin{abstract}
Surveys on the Kent Peninsula and King William Island in the central Canadian Arctic in 2006 documented 546 Paleoeskimo dwelling features spanning about 3800 years $\left(4500-800{ }^{14} \mathrm{C}\right.$ years BP), essentially the time span of the Paleoeskimos in the region. Feature elevation above sea level, corroborated by a series of radiocarbon dates, appears to indicate that Paleoeskimo occupation passed through a series of boom-and-bust cycles, the first being the most prominent. Following the first peopling about $4500{ }^{14} \mathrm{C}$ years BP, populations rose to their all-time maximum between about 4200 and $3600{ }^{14} \mathrm{C}$ years $\mathrm{BP}$. This rise was followed by a dramatic crash: a pattern that parallels histories previously documented both west and east of the region. A slight recovery between 3100 and $2500{ }^{14} \mathrm{C}$ years BP was temporary, and a final slight recovery between 2000 and $800{ }^{14} \mathrm{C}$ years BP was followed by the disappearance of the Paleoeskimos. No compelling evidence yet points to the cause of the population crashes; climate change and resource over-exploitation, acting alone or in concert, are equally plausible at this time. Dispersed nuclear families or small extended families characterized Paleoeskimo settlement patterns for most of the year in this region, as elsewhere, but annual aggregations probably involved 100 or more people. Minimal social units do not appear to have changed during seasonal aggregations in Pre-Dorset times. By Dorset times (after $2500{ }^{14} \mathrm{C}$ years BP), however, minimal social units at times appear to have melded together to form one or a few larger units living in one or several large dwellings. The latter may represent the social precursor of later Dorset longhouse aggregations. The persistent difference in average dwelling size between the Kent Peninsula sites and those on King William Island remains unexplained.
\end{abstract}

Key words: archaeology, Paleoeskimo, Pre-Dorset, Dorset, sea-level history, paleodemography, dwellings, radiocarbon

RÉSUMÉ. Des levés de la presqu'île Kent et de l'île du Roi-Guillaume dans le centre de l'Arctique canadien réalisés en 2006 ont permis de répertorier 546 détails d'habitations paléoesquimaudes s'étendant sur environ 3800 ans (de 4500 à $800{ }^{14} \mathrm{C}$ années BP), ce qui représente essentiellement l'horizon temporel des Paléoesquimaux dans la région. L'évaluation des détails au-dessus du niveau de la mer, corroborée par une série de dates déterminées au carbone 14, semble indiquer que la période d'occupation des Paléoesquimaux est passée par une série de cycles d'expansion et de ralentissement, le premier étant le plus éminent. Après le premier peuplement vers $4500{ }^{14} \mathrm{C}$ années $\mathrm{BP}$, les populations ont atteint leur summum de tous les temps entre 4200 et $3600{ }^{14} \mathrm{C}$ années BP. Cette montée a été suivie d'un déclin dramatique : la tendance est le parallèle de l'historique répertorié à l'ouest et à l'est de la région. Temporairement, il y a eu une légère reprise entre 3100 et $2500{ }^{14} \mathrm{C}$ années $\mathrm{BP}$, et une dernière reprise de peu d'envergure entre 2000 et $800{ }^{14} \mathrm{C}$ années BP, suivie de la disparition des Paléoesquimaux. À ce jour, aucune preuve évidente ne nous laisse comprendre les déclins de population. À ce stade-ci, le changement climatique tout comme la surexploitation des ressources sont des causes toutes aussi plausibles les unes que les autres. Des familles nucléaires dispersées ou de petites familles étendues caractérisaient les modèles de peuplement des Paléoesquimaux pendant la plus grande partie de l'année dans cette région, tout comme ailleurs, bien que les rassemblements annuels regroupaient une centaine de personnes ou plus. Les unités sociales minimales ne semblent pas avoir changé durant les rassemblements saisonniers du pré-Dorset. Cependant, à l'époque du Dorset (après $2500{ }^{14} \mathrm{C}$ années BP), les unités sociales minimales semblent parfois s'être fusionnées pour former une ou quelques unités plus grandes vivant dans une ou plusieurs grandes habitations. Ces habitations étaient peut-être les précurseurs des agglomérations de maisons longues du Dorset. La différence persistante caractérisant la taille de l'habitation moyenne entre les sites de la péninsule de Kent et ceux de l'île du Roi-Guillaume demeure inexpliquée.

Mots clés : archéologie, paléoesquimau, pré-Dorset, Dorset, historique du niveau de la mer, paléodémographie, habitations, carbone 14

Traduit pour la revue Arctic par Nicole Giguère.

\footnotetext{
${ }^{1}$ Geological Survey of Canada, 601 Booth Street, Ottawa, Ontario K1A 0E8, Canada and Department of Geography, Memorial University, Saint John's, Newfoundland A1B 3X9, Canada; adyke@nrcan.gc.ca

${ }^{2}$ Department of Anthropology, McGill University, 855 Sherbrooke Street West, Montreal, Quebec H3A 2T3, Canada; james.savelle@mcgill.ca

(C) The Arctic Institute of North America
} 


\section{INTRODUCTION}

This paper presents the results of the first systematic surveys of Paleoeskimo sites on the Kent Peninsula and King William Island in the central Canadian Arctic (Fig. 1). We focus on the changes with elevation in the abundance of dwelling features on raised beach sequences - a proxy for age - and on individual dwelling sizes, as well as on overall site sizes and characteristics. We present the first radiocarbon age determinations from sites in these regions and compare the results to those of our previous surveys in regions to the west and east along the Northwest Passage. We present summaries of primary field and radiocarbon data, comment on changing levels of human occupation and social organization, and explore the broader regional synchronism of demographic changes. We also present new relative sea-level (RSL) curves and use these to assess archaeological site chronology.

Paleoeskimos were the first people to occupy the Canadian Arctic Archipelago, parts of the Canadian Arctic mainland, and Greenland. Although the Paleoeskimos are known by various cultural names, in the central Canadian Arctic the early Paleoeskimo groups are generally referred to as the Pre-Dorset culture, and the late groups, as the Dorset culture. The Dorset culture is thought to have derived from the Pre-Dorset in the Canadian Arctic about $2500{ }^{14} \mathrm{C}$ years BP and to have been replaced by Neoeskimos from the Bering Strait region between 1000 and $700{ }^{14} \mathrm{C}$ years BP. No previous studies of the Paleoeskimo from our survey areas have been published. However, Pre-Dorset, Dorset, and Thule (Neoeskimo) sites have been described and dated from southeastern Victoria Island, directly north of the Kent Peninsula (Taylor, 1972; Friesen, 2004), and Thule culture sites have been studied on southern King William Island (Mathiassen, 1927; Rasmussen, 1931; Savelle, 1987a).

\section{METHODS}

From each of three aircraft-deployed field camps (Kent Peninsula, Peel Inlet, and Cape Jane Franklin; Fig. 1), we surveyed glacio-isostatically raised beach sequences and other terrain by all-terrain vehicles between 7 and 31 July 2006. An additional camp farther west on the Kent Peninsula was occupied for a few days, but no Paleoeskimo sites were recorded there. We inspected beaches between modern sea level and the highest accessible terrain in each area, at about $80-100 \mathrm{~m}$ elevation. The areas around all three field camps lie entirely below the limit of postglacial marine submergence, which is at $175-200 \mathrm{~m}$ elevation in the region (Dyke et al., 2005). We concentrated our search on middle and late Holocene relict shorelines, generally the lower $40 \mathrm{~m}$, where archaeological sites proved to be most abundant. During about six days at each camp, we searched linear coastal segments of about $20 \mathrm{~km}$. Two observers traversed the terrain each day in ATVs, driving roughly in parallel lines. They proceeded obliquely upslope and down, moving away from and back toward camp, so that most of the terrain within the search area was fairly uniformly and thoroughly inspected. We recorded the elevations above high tide line of all archaeological sites using a surveying altimeter. Altimeter readings were corrected for changes in atmospheric pressure and are probably accurate to $\pm 0.5 \mathrm{~m}$. All feature locations were recorded using a hand-held GPS. Feature sizes were measured with a steel tape, and dwelling features were classified according to familiar Paleoeskimo architectural types (Ryan, 2003; Sutherland, 2003; Savelle and Dyke, in press). In the case of tent rings, dimensions were taken on what appeared to have been the original outside dimensions. That is, any obviously disturbed or outof-place stones peripheral to what appeared to have been the original structure were not included. This approach is further discussed below under Social Dynamics Based on Dwelling Size.

Small samples of charcoal and burnt moss from hearths and of wood and bone debitage on or near the surface were collected for radiocarbon dating. Charcoal and wood samples were sent to the Geological Survey of Canada Paleoecology Laboratory for identification. After leaching in multiple baths of $\mathrm{HCl}$ to remove secondary carbonate, which typically coated and infused them, samples were identified by cell anatomy as either local dwarf willow (Salix sp.) or spruce (Picea spp.) driftwood. Willow charcoal grains were chosen for dating where present; otherwise, driftwood charcoal was used, if mammal food bone was not available. Those mammal bones submitted for dating were longbone fragments with distinct evidence of marrow cavities and with curvatures indicating that they came from large animals in the caribou or muskox size range. Because the bones are not identifiable to genus, we used their stable isotope values to assess whether they are compatible with being caribou or muskoxen. The burnt moss samples were identified as Dicranum sp., a terrestrial (as opposed to aquatic) genus, at the herbarium of the Canadian Museum of Nature. Samples of marine shells, driftwood, and whale bones were also collected from raised beaches and raised deltas in order to better define RSL histories. All bone samples were mechanically reduced to clean interior portions prior to submission. Radiocarbon samples were analyzed at the University of California-Irvine Accelerator Mass Spectrometry facility (UCIAMS). Bone dates were run on ultrafiltered collagen fractions larger than 10 kiloDaltons $(\mathrm{kD})$ in size after collagen quality was assessed through percent yield and stable isotope values. The dates on terrestrial materials were calibrated (rounded to decade) using the online version of CALIB 5.0.2 (accessed on 25 February 2008 ) and the \pm 2 sigma range with the largest area under the probability curve (Stuiver et al., 1998). Dates on marine materials were calibrated using the marine 04.14 calibration dataset and $\mathrm{a} \pm 2$ sigma range. For marine shell dates, a "delta R" value of $240 \pm 50$ years was applied (total correction 740 years), whereas for whale bone dates, a delta $R$ value of $0 \pm 50$ years was applied, as discussed below. 

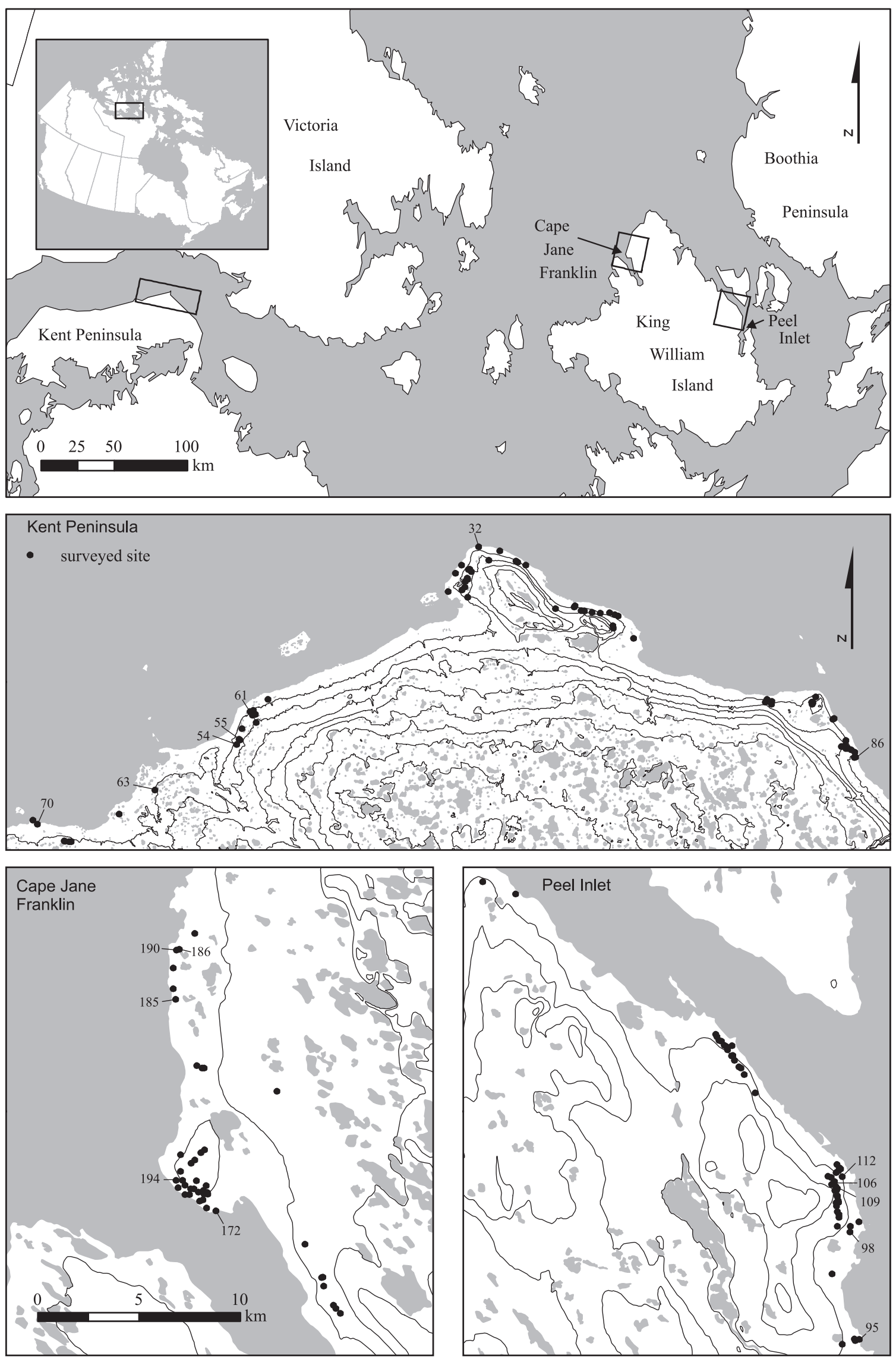

FIG. 1. Locations of the Kent Peninsula and King William Island in the central Canadian Arctic, showing the Paleoeskimo sites (•) in the three main survey areas. Contour interval is $20 \mathrm{~m}$. 
Calibrated dates are presented in the tables, but our discussion uses the radiocarbon time scale.

\section{ENVIRONMENT}

The Kent Peninsula, on the Canadian Arctic Mainland coast opposite Victoria Island, is within the Low Arctic vegetation belt as defined by Edlund (1986), though near its northern limit, and King William Island is within (though near the southern limit of) the Middle Arctic belt. Climate data for 1971-2000 from Cambridge Bay, the nearest community about $30 \mathrm{~km}$ east of the Kent Peninsula, indicate a mean annual temperature of $-14.4^{\circ} \mathrm{C}$ (compared to $-32.8^{\circ}$ for January and $8.4^{\circ} \mathrm{C}$ for July) and mean annual precipitation of $138.8 \mathrm{~mm}$ (Environment Canada, 2008). Climate data from Gjoa Haven on southeastern King William Island are not available for the same period, but winter conditions there probably resemble those at Cambridge Bay, whereas summers are probably somewhat colder. The Middle Arctic typically has a vegetation cover of $30-50 \%$. Willow is the only large shrub, and common plants include sedges, grasses, forbs, and ericaceous shrubs. The Middle Arctic lies between the High Arctic (polar desert), where the vegetation cover is typically $1-5 \%$, and the Low Arctic, where vegetation cover commonly attains $50-100 \%$ and where dwarf birch (Betula glandulosa, B. nana) and alder (Alnus spp.) may be present as additional large shrubs. We noted dwarf birch and semi-erect willows commonly on the central Kent Peninsula, but not at the northern tip of the peninsula where our archaeological surveys were conducted. In both the Middle and High Arctic, vegetation cover is strongly suppressed on highly alkaline substrates and is enhanced on the nutrient-rich acidic substrates. On both substrates, plant cover responds markedly to soil drainage conditions.

Our survey areas are dominated by rather uniform flights of raised beaches (see site photographs referred to below) that are composed mainly of gravel, with quartzite clasts predominating on the Kent Peninsula and carbonate (dolomitic) clasts predominating on King William Island. The quartzite clasts, commonly cobbles, are extensively covered with crustose lichens on both archaeological and natural surfaces, but vascular plant cover on these well-drained raised beaches is typically minimal. Because of limited nutrient availability from dolomite and the excessively well-drained conditions, and despite a general Middle Arctic location, vegetation cover on the raised beaches on King William Island is typically only $1-5 \%$, and even lichens and dwarf willows are rare. However, vegetation cover on these beaches is enhanced at sites of former human occupation because of nutrients added from small amounts of food and other organic refuse, which makes these features conspicuous. In both regions, vegetation cover is enhanced in swales and small wetlands between raised beaches and on glacial till, presumably because of its moisture-holding capacity. Furthermore, areas of finer-grained raised marine sediment and alluvium support greater vegetation covers, sufficient to support small caribou and muskox herds.

Our study sites are along the central reach of the Northwest Passage. Coronation Gulf extends westward from the Kent Peninsula, and Queen Maud Gulf separates the Kent Peninsula and King William Island. M'Clintock Channel extends north of the latter. M'Clintock Channel has a near-perennial sea-ice cover, with summer ice that is much more persistent than ice in areas both east and west. One consequence of this persistent ice cover is that the marine molluscan community of M'Clintock Channel is more impoverished than that of Coronation Gulf. For example, Mytilus edulis and Macoma balthica reach their range limits (from the Pacific Ocean) in Coronation Gulf and fail to reach M'Clintock Channel (Dyke et al., 1996a). The entire central Northwest Passage is beyond the normal modern range of the bowhead whale (Dyke et al., 1996b).

Today the chilling effect of onshore winds renders the M'Clintock Channel region the most severe summertime environment along the former west-to-east path of the Paleoeskimo across the North American Arctic. The sea ice is a mix of first-year (75\%) and multi-year ice. The channel opens partially in many summers, mainly through in situ ablation and preferential northward recession of the floe edge along the Boothia Peninsula coast east of King William Island (Barber and Iacozza, 2004). The average date of opening along this coast in the years AD 1980-2000 was in late August, and the average date of freeze-up was in late September. The modern beach along much of the coast of King William Island is a fairly well formed gravel ridge, though it is not as thick as that on the Kent Peninsula and it is much more disturbed by the shoreward pushing action of sea ice. The raised beaches, where almost all of the Paleoeskimo dwelling sites are located, are similar in form to the modern beach, particularly in the lower $50 \mathrm{~m}$ or so.

The Quaternary geology and general environmental conditions in the study areas are described in Blake (1963), Craig (1964), Hélie (1985), and Dyke and Dredge (1989). Postglacial uplift rates were poorly documented in this part of the Arctic (Dyke et al., 1991), but both regions show evidence of strong late Holocene emergence.

\section{SIGNIFICANT FAUNAL RESOURCES}

Currently and historically, the most important mammalian species to the Netsilik Inuit of the King William Island area and to the Copper Inuit of the Coronation Gulf area are ringed seals (Phoca hispida) and caribou (Rangifer tarandus). Muskoxen (Ovibos moschatus, which average $340 \mathrm{~kg}$ ) are abundant on Victoria Island and the Kent Peninsula and are present on King William Island. Ringed seals occupy the region year-round. They rely on landfast sea ice, maintaining breathing holes through the ice and locating their snow-covered breeding dens on its surface. Sealing was traditionally the primary winter and spring subsistence activity, seals being abundant off all coasts (Ross, 1835; 
M'Clintock, 1859; Brice-Bennett, 1976; Farquharson, 1976).

Barren-ground caribou (R. t. tarandus; $80-110 \mathrm{~kg}$ ) are summer migrants to King William and Victoria islands from the Arctic Mainland, crossing the channels on sea ice at narrow points, such as off the northern tip of the Kent Peninsula. Although there are no early historical population estimates, caribou numbers are believed to have drastically declined with the introduction of the rifle in the 1930s and 1940 s, to the point that the northward migration to King William and Victoria islands stopped. During the early European contact period, however, and presumably the prehistoric period, they migrated onto King William Island (Amundsen, 1908; Stockpole, 1965). Large Thule archaeological sites are located near caribou crossings (Mathiassen, 1927; Savelle, 1987a), as they are on Victoria Island (Taylor, 1972). Peary caribou (R. t. pearyi; $55-80 \mathrm{~kg}$ ), which reside year-round farther north, may also have occupied King William Island prehistorically.

Muskoxen were traditionally hunted by Inuit in the Kent Peninsula-Victoria Island region and south of King William Island. They were presumably a significant resource for the Paleoeskimo, perhaps more so in the west. They appear to have been relatively scarce in the east, where no muskoxen were reported for a number of years in the $1950 \mathrm{~s}$ (Barr, 1991:52-53), presumably reflecting their general demise because of over-hunting during the 19th and early 20th centuries. However, muskoxen are gradually repopulating the area. During the mid-1990s, more than 70000 animals occurred on western Victoria and neighbouring Banks islands (Gunn et al., 1991; Heard, 1992). Likewise, the muskox is gradually repopulating King William Island, with 137 reported in 2000-01 (Nunavut Wildlife Management Board, 2002).

Arctic char (Salvelinus alpinus) is an important anadromous fish species, harvested primarily during the summer and fall, and lake trout (Salvelinus namaycush), arctic cod (Boreogadus saida) and whitefish (Coregonus clupeaformis) are also important food stocks. While data for the traditional Netsilik and Copper Inuit are not available, if data for other eastern Arctic coastal Inuit groups are any indication, fish probably constituted a significant part of the Neoeskimo, and presumably of the Paleoeskimo, diet (Kelly, 1995:67; Stewart, 2006).

\section{RESULTS AND DISCUSSION}

\section{Relative Sea-level History and Faunal Ranges}

Because few age constraints were previously available for the RSL history of either the Kent Peninsula (Kerr, 1996) or King William Island (Dyke et al., 1991), we summarize currently available data in Figure 2. Dates on archaeological sites discussed below comprise the "on or above curve" series on these graphs, although realistically a maximum limiting date on an archaeological site (e.g., a
Kent Peninsula, NU

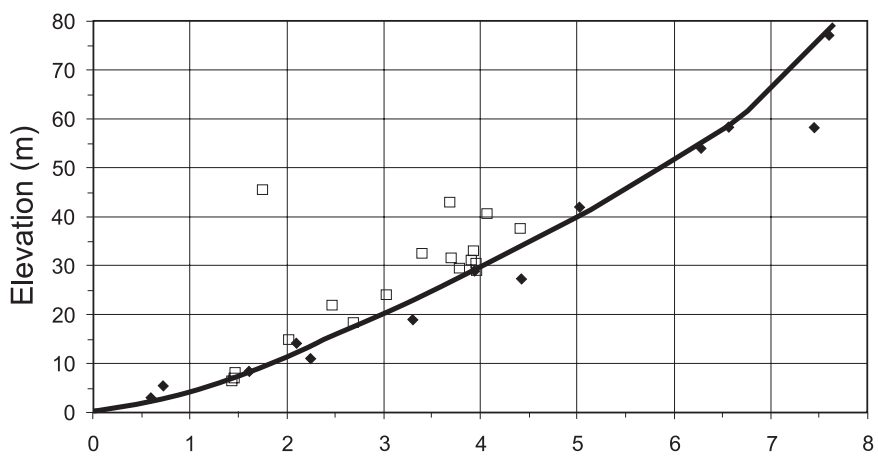

King William Island, NU

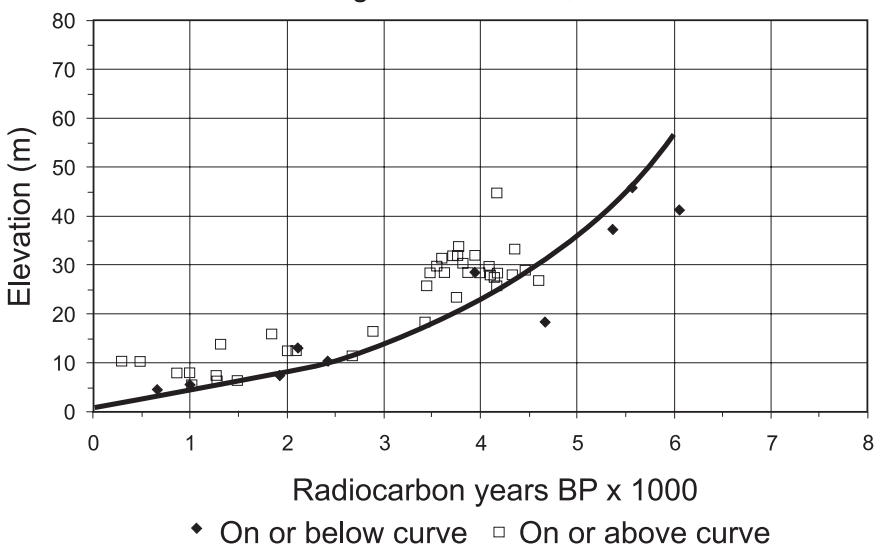

FIG. 2. Relative sea-level curves. Barring elevation or age anomalies, dates on marine materials (black diamonds) should fall on or below the RSL curve and dates on archaeological materials (open squares) should fall on or above the curve. The King William Island plot includes dates on Thule archaeological sites, not discussed in the text.

date on driftwood charcoal that is much older than the occupation) could fall below the RSL curve. Dates on marine shells, whale bones, and driftwood-the "on or below curve" series of the graphs-are listed in Table 1. Marine shell ages in these plots (Fig. 2) are reduced by 740 years from the conventionally normalized ages listed in Table 1 to account for the average empirical age of the modern marine reservoir, as measured in pre-bomb molluscs (McNeely et al., 2006). We reduce bowhead whale bone ages by 400 years, which is close to the global ocean reservoir age. We lack an empirical reservoir correction for bowheads in this region. However, these animals would have spent only brief intervals in the central Arctic each year, and comparisons of driftwood-whale bone age pairs from raised beaches in the Canadian Arctic Archipelago indicate that a larger correction for whale bone dates might be excessive (Dyke et al., 1996c). The elevations plotted for the "on or below curve" series in Figure 2 are those for the minimum RSL to which the samples pertain. For surface shells, whale bones, and driftwood, this is the same as sample elevation. For shells from sections through sediment, which here are thin, sandy raised deltas along small streams, the minimum RSL is the elevation of the top of the delta. 
TABLE 1. Radiocarbon dates on marine shells, whale bones, and driftwood used for relative sea-level (RSL) curves; all ages conventionally normalized on the basis of measured or assumed fractionation. Laboratory codes are for UCIAMS dates unless otherwise indicated. Area in last column is the area under the probability distribution for the calibration. The stated range is that with the largest area.

\begin{tabular}{|c|c|c|c|c|c|c|}
\hline Laboratory Code & Taxon Dated & Elevation (m) & Min RSL (m) & ${ }^{14} \mathrm{C}$ Age $\left(\delta^{13} \mathrm{C}\right)$ & Calib 5.0.2 2-Sigma Range & Area \\
\hline \multicolumn{7}{|l|}{ Kent Peninsula: } \\
\hline 30332 & Mya truncata & 77 & 77 & $8345 \pm 20$ & $8419-8740$ & 1.000 \\
\hline 29149 & Mytilus edulis & 48 & 58.5 & $7310 \pm 15$ & $7452-7651$ & 1.000 \\
\hline AECV-948C ${ }^{1}$ & Mya truncata, Mya arenaria & 58 & 58 & $8200 \pm 150$ & $8095-8890$ & 1.000 \\
\hline 30331 & Hiatella arctica & 47 & 54 & $7025 \pm 20$ & $7203-7417$ & 1.000 \\
\hline 29148 & Mytilus edulis & 35 & 42 & $5760 \pm 20$ & $5741-6046$ & 1.000 \\
\hline 29150 & Mytilus edulis & 24 & 29 & $4680 \pm 15$ & $4468-4791$ & 0.991 \\
\hline AECV-947C 1 & Mya truncata, Macoma calcarea & 27.4 & 27.4 & $5170 \pm 100$ & $4941-5542$ & 1.000 \\
\hline 29147 & Mytilus edulis & 13 & 19 & $4050 \pm 20$ & $3606-3906$ & 1.000 \\
\hline 29146 & Mytilus edulis & 9 & 14 & $2845 \pm 15$ & $2131-2421$ & 1.000 \\
\hline 29152 & Serripes groenlandicus & 5 & 11 & $2995 \pm 15$ & $2336-2661$ & 1.000 \\
\hline 29151 & Mytilus edulis & 8.5 & 8.5 & $2355 \pm 15$ & $1551-1829$ & 1.000 \\
\hline 29586 & Balaena mysticetus & 5.5 & 5.5 & $1130 \pm 20(-16.1)$ & $590-790$ & 0.983 \\
\hline 29233 & Balaena mysticetus & 3 & 3 & $1000 \pm 15(-15.1)$ & $506-658$ & 1.000 \\
\hline \multicolumn{7}{|c|}{ King William Island: } \\
\hline S-2682 & Mya truncata, Hiatella arctica & 85 & 85 & $8120 \pm 210$ & $7924-8924$ & 1.000 \\
\hline 29161 & Picea driftwood & 45.5 & 45.5 & $5575 \pm 15$ & $6311-6400$ & 1.000 \\
\hline 30333 & Hiatella arctica & 41 & 41 & $6795 \pm 20$ & $6931-7212$ & 1.000 \\
\hline S-2681 & Balaena mysticetus & 37 & 37 & $5780 \pm 100$ & $5924-6409$ & 1.000 \\
\hline 29235 & Balaena mysticetus & 28 & 28 & $4340 \pm 20(-15.4)$ & $4304-4647$ & 1.000 \\
\hline 29145 & Hiatella arctica & 18 & 18 & $5415 \pm 15$ & $5425-5652$ & 1.000 \\
\hline 29587 & Balaena mysticetus & 12.5 & 12.5 & $2520 \pm 20(-15.1)$ & $2043-2318$ & 1.000 \\
\hline GSC-3548 & Astarte sp. & 10 & 10 & $3160 \pm 120(1.1)$ & $2331-2976$ & 1.000 \\
\hline GSC-5819 & Pinus driftwood & 7 & 7 & $1930 \pm 80(-26.1)$ & $1696-2064$ & 0.984 \\
\hline 29234 & Balaena mysticetus & 5 & 5 & $1400 \pm 15(-14.6)$ & $810-1070$ & 1.000 \\
\hline GSC-5820 & Picea driftwood & 4 & 4 & $660 \pm 50(-25.0)$ & $549-679$ & 1.000 \\
\hline \multicolumn{7}{|l|}{12.5 m bowhead: } \\
\hline $29587^{2}$ & $10 \mathrm{kD}$ collagen & & & $2520 \pm 20(-15.1)$ & $2047-2316$ & 1.000 \\
\hline 35602 & $\mathrm{KOH}$ extracted collagen & & & $2425 \pm 25(-17.7)$ & $1916-2253$ & 1.000 \\
\hline 35603 & Gelatin from $\mathrm{KOH}$-collagen & & & $2455 \pm 25(-15.4)$ & $1959-2284$ & 1.000 \\
\hline 35594 & XAD-gelatin from $\mathrm{KOH}$-collagen & & & $2500 \pm 25(-13.6)$ & $2009-2306$ & 1.000 \\
\hline \multicolumn{7}{|l|}{28 m bowhead: } \\
\hline $29235^{2}$ & $10 \mathrm{kD}$ collagen & & & $4340 \pm 20(-15.4)$ & $4304-4647$ & 1.000 \\
\hline 30447 & $10 \mathrm{kD}$ collagen & & & $4335 \pm 15$ & $4304-4632$ & 1.000 \\
\hline 35604 & $\mathrm{KOH}-$ collagen & & & $4340 \pm 25(-16.8)$ & $4298-4651$ & 0.997 \\
\hline 35605 & Gelatin from $\mathrm{KOH}$-collagen & & & $4350 \pm 25(-14.5)$ & $4332-4689$ & 1.000 \\
\hline 35595 & XAD-gelatin from $\mathrm{KOH}$-collagen & & & $4370 \pm 25(-15.2)$ & $4361-4715$ & 0.999 \\
\hline
\end{tabular}

${ }^{1}$ From Kerr (1996).

${ }^{2}$ Collagen samples from the same bowhead whale bones listed earlier in the table, after pretreatment at Stafford Laboratories.

The dates on Mytilus edulis shells, in particular, from the Kent Peninsula define a smooth curve of RSL fall from $58.5 \mathrm{~m}$ at $6570{ }^{14} \mathrm{C}$ years BP (UCIAMS-29149, reservoir corrected) down to $8.5 \mathrm{~m}$ at $1615{ }^{14} \mathrm{C}$ years BP (UCIAMS29151, reservoir corrected). A M. edulis sample at $29 \mathrm{~m}$ has a reservoir-corrected age of $3940 \pm 15{ }^{14} \mathrm{C}$ years BP (UCIAMS-29150), which is essentially identical to the age of $3955 \pm 15$ BP (UCIAMS-30381) on Picea charcoal from a hearth at the same elevation (the symbol for the shell date is overprinted by that for the charcoal date on the graph). A line forming a tight lower bound to the Kent Peninsula archaeological dates would be essentially the same as a line forming a tight upper bound to the dates on marine materials. Hence, we consider the Kent Peninsula curve to be well constrained below $80 \mathrm{~m}$ elevation.

Interpretation of the King William Island RSL history is more problematic, depending on the interpretation of two samples of bowhead whale bones. These samples, one from a skull base at $12 \mathrm{~m}$, the other a complete vertebra at $28 \mathrm{~m}$, were found on the surface of raised beaches. Both appear to be too young with respect to the dates on archaeological sites (Fig. 2). The samples appeared normal in terms of the percent yield, the colour of the collagen extract, and their stable isotope fractionation values (John Southon, University of California at Irvine, pers. comm. 2007). Furthermore, a second age determination on one of them returned a duplicate result. Because of suspect ages, however, both samples were re-prepared at Stafford Research Laboratories (Lafayette, $\mathrm{CO}$ ) in an attempt to assess the presence of chemical contaminants such as humic acids. Three additional dates were run on different chemical extractions of each sample (Table 1). All extractions returned results similar to the first determinations. We conclude, therefore, that both ages are correct. Hence, either (a) we are dealing with 
elevation anomalies for both bone samples, or (b) many of the archaeological dates are too old, which is not to say inaccurate. If all of the archaeological dates to the right of a line joining the two whale bone dates were on driftwood charcoal, we could conclude that (b) is probable. However, three of the dates to the right of that line are on Salix charcoal, and two are on terrestrial bones. Thus, we feel that we are dealing with elevation anomalies, due either to altimeter-reading errors, or to sea-ice pushing of the bones landward above their contemporary shorelines, or to upslope movement of the bones by people (only people, as opposed to animals, could have moved the large skull base). Ignoring these two whale bone samples, a reasonable RSL curve is defined by the three driftwood samples at $4 \mathrm{~m}, 7 \mathrm{~m}$, and $45.5 \mathrm{~m}$; by the $5 \mathrm{~m}$ bowhead date $\left(1000{ }^{14} \mathrm{C}\right.$ years BP, reservoir corrected); by a date on molluscs (Astarte sp.) in littoral sand at $10 \mathrm{~m}\left(2420{ }^{14} \mathrm{C}\right.$ years $\mathrm{BP}$, reservoir corrected); and by the generally accordant lower bound of the archaeological dates. Nevertheless, assuming a smooth fall of RSL as is typical of this strongly uplifted region (Dyke et al., 1991), a few of the archaeological dates may be a century or more too old, with UCIAMS-30443 (4610 BP) on Picea charcoal at $26.5 \mathrm{~m}$ (Fig. 2a) the most conspicuous. The age of that site is realistically less than 4200 BP.

Shorelines contemporaneous with the generally accepted earliest Pre-Dorset $\left(4500{ }^{14} \mathrm{C}\right.$ years BP) and earliest Dorset $\left(2500{ }^{14} \mathrm{C}\right.$ years BP) peoples are thus now found at about $38 \mathrm{~m}$ and $17 \mathrm{~m}$, respectively, on the Kent Peninsula, and at about $30 \mathrm{~m}$ and $10 \mathrm{~m}$, respectively, on King William Island.

Because Mytilus edulis is a key thermophile in Arctic waters, its apparent presence in eastern Coronation Gulf, approximately its present range limit, throughout the middle and late Holocene (Table 1; fresh mussel shells are also seen on the modern beach) - and its apparent absence throughout that time on King William Island, where we found no trace of it - probably indicate long-term stability of its range limit in this region. However, centennial range retractions cannot be ruled out without further dating. Bowhead whale remains are rather rare in the region, but much more searching needs to be done to document them fully. Nevertheless, at least brief intervals of bowhead incursion occurred during the middle and late Holocene. In addition to the specimens listed in Table 1, a bowhead mandible found at a historic period Inuit campsite on northwestern King William Island (no RSL significance) gave a normalized age of $5530 \pm 20{ }^{14} \mathrm{C}$ years BP (UCIAMS-29236).

\section{General Archaeological Site Distribution}

All features are located on well-drained beach gravel, typically cobble-to-boulder gravel on the Kent Peninsula, but fine-to-medium gravel on King William Island. Sand beaches are common on parts of the Kent Peninsula and are subject to wind deflation and dune migration. We found no dwelling features in sandy areas, a pattern that we have also observed in other surveys. All beaches surveyed on King William Island were composed of gravel. In all survey areas, there is a distinct clustering of Paleoeskimo features on headlands (Fig. 1), even though gravel substrates are almost equally common in coves. Sites show no particular affinity for proximity to ponds or streams.

In this paper, as in our previous reports, we define a site as an individual dwelling feature isolated from, and generally not within sight of, any others, or as an obvious grouping of two or more dwellings at the same elevation, or at closely similar elevations on adjacent beach ridges, where the dwellings are spaced a few metres apart.

\section{Feature Frequencies and Ages}

We recorded 219 Paleoeskimo dwelling features on the Kent Peninsula, 168 in the Peel Inlet area, and 159 in the Cape Jane Franklin area in nearly equal periods of searching time. We found no Paleoeskimo sites at elevations higher than $50 \mathrm{~m}$, nor are we aware of any inland sites in these regions. The three graphs of frequency of features by elevation show some remarkable similarities (Fig. 3). Each histogram shows the most prominent mode above $25 \mathrm{~m}$ and two or more minor modes on lower beaches, with the youngest features at 5 to $7 \mathrm{~m}$ elevation. The first mode on the Kent Peninsula is $4 \mathrm{~m}$ higher than those on King William Island, the direction and roughly the difference that might be expected from the RSL curves (Fig. 2). The distribution of relatively high-level sites on the Kent Peninsula gives the impression of a gradual rise of population to a clear maximum associated with the 29-30 m beach, followed by a precipitous decline. A similar pattern of gradual early increase may be inferred less confidently from the King William Island sites, but there the early rise may have been interrupted by a brief decline associated with the $29 \mathrm{~m}$ (Peel Inlet) and $30 \mathrm{~m}$ beaches (Cape Jane Franklin). Nevertheless, viewed jointly, the King William Island sites show an equally precipitous decline at the $25 \mathrm{~m}$ level.

It is difficult to explain the tight clustering of sites by elevation, especially such striking similarities, as indicating anything other than sudden changes in population by people camped close to the shoreline. Otherwise the sites should be uniformly or randomly distributed and should not be limited to the middle and late Holocene raised beaches. If these features were occupied when the shoreline was on average only a few metres below the campsites, as the distributions suggest, the RSL histories (Fig. 2) would indicate that the sites above $17 \mathrm{~m}$ on the Kent Peninsula and above $10 \mathrm{~m}$ on King William Island, which constitute the vast majority of sites, date from Pre-Dorset time, with Dorset weakly represented, particularly on King William Island.

In many areas of the Arctic, Dorset people appear to have been less residentially mobile and more logistically organized than were the Pre-Dorset (e.g., Maxwell, 1985; McGhee, 1996). Thus decreases in numbers of dwelling features in those areas during Dorset times may be a reflection of increased sedentism. However, features that would indicate significantly increased sedentism, such as semisubterranean dwellings or other architecturally substantial 

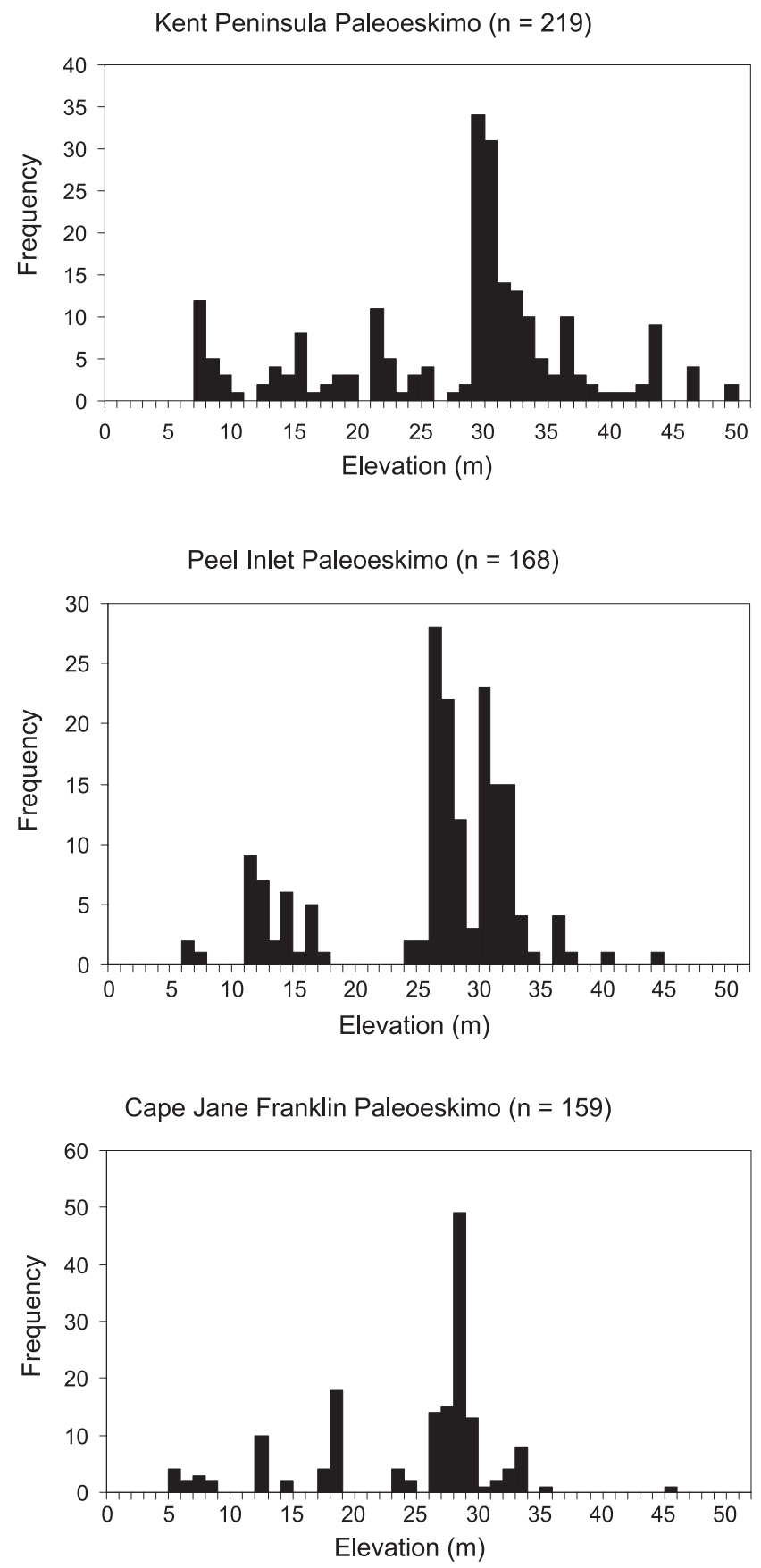

FIG. 3. Distribution of dwelling features by elevation above sea level. Note different $y$-axis scales.

dwellings, were not recorded in our surveys. Brief occupation of sites is further indicated by the characteristically sparse artefact remains and faunal refuse. Thus, we interpret feature frequency to be more closely related to population levels than to degree of residential mobility.

Bearing in mind that some dates are maximum-limiting ages, radiocarbon dates are consistent with the suggested ages of the occupation modes and with the notion of synchronism of the main early modes between the Kent Peninsula and King William Island. We obtained 20 radiocarbon dates on as many dwelling features from the Kent Peninsula
(Table 2) and 39 dates on as many features from King William Island (Table 3). A few results depart from expectation by violating the assumption that the feature was occupied when RSL was just below the site. Specifically, the two highest-dated features on the Kent Peninsula, adjacent box hearths at $45.5 \mathrm{~m}$, derive from Late Dorset, rather than early Pre-Dorset, occupation (UCIAMS-30328, -30360). And two of the Picea charcoal dates from King William Island evidently result from the burning of ancient driftwood (UCIAMS-30437, -30325), an expected type of dating noise in this region. Otherwise, the upper group of features on the Kent Peninsula date between about 4400 and 3400 (mainly 4400 and 3700$){ }^{14} \mathrm{C}$ years BP. Of eight age determinations from that interval, six are on Salix charcoal; the other two on Picea charcoal are unexceptional. The upper group of sites at Peel Inlet date between 4100 and $3450{ }^{14} \mathrm{C}$ years BP, the oldest of 11 dates being on Salix charcoal. The upper group at Cape Jane Franklin, based on 13 age determinations, date between 4610 and $3760{ }^{14} \mathrm{C}$ years BP, both the older and younger being on Picea charcoal. Of two Salix and two bone dates from here, the oldest are 4370 and $4195{ }^{14} \mathrm{C}$ years BP, respectively. However, the stable-isotope values for that bone (UCIAMS-29245), as well as two others (UCIAMS-29242, -29246), are atypical for terrestrial bones, and resemble those of polar bear (Dyke and Savelle, unpubl. data). The two earliest Picea dates, 4610 and 4475 ${ }^{14} \mathrm{C}$ years BP, though not unacceptable archaeologically, appear to be about 100 and 300 years too old, respectively, to fit our interpretation of the RSL history (above). Otherwise, our driftwood charcoal dates fall within the same age range as the others and thus are not evidently problematic. All these dates fall comfortably into the early Pre-Dorset period in Arctic Canada (McGhee, 1996), and several are amongst the earliest available from the Canadian Arctic.

If our RSL curve is correct, sites below $17 \mathrm{~m}$ on the Kent Peninsula are of obligate Dorset age. The relatively few features between 18 and $25 \mathrm{~m}$ represent possible late Pre-Dorset occupations. We obtained only three radiocarbon samples from these sites, and the age determinations $\left(3025-2465{ }^{14} \mathrm{C}\right.$ years BP) are appropriate for late Pre-Dorset. Thus our current sample of radiocarbon dates leaves a chronological gap between 3405 and 3025 (and nearly $3695 \mathrm{BP}$ ), corresponding to the 25-28 m beach levels of Figure 3. Sites below $17 \mathrm{~m}$ on the Kent Peninsula have yielded a late Early Dorset (or early Middle Dorset) age at $15 \mathrm{~m}\left(2025{ }^{14} \mathrm{C}\right.$ years BP) and a narrow range of Late Dorset ages from sites between 6.5 and $8 \mathrm{~m}\left(1430,1460,1465\right.$, and $1480{ }^{14} \mathrm{C}$ years BP, all on burnt moss). On King William Island, only sites below $10 \mathrm{~m}$ are of obligate Dorset age, according to our RSL curve. However, of the six dates available from features between 11 and $18 \mathrm{~m}$ elevation, only three are of Pre-Dorset vintage, and the earliest of these is a maximum-limiting age. Thus, the chronological gap in our current sample from King William Island is about 3450-2900 BP. The remaining sites fall chronologically into the late-Middle and mainly Late Dorset. These sites, especially Late Dorset, are proportionally over-represented in our radiocarbon sampling, mainly 
TABLE 2. Radiocarbon dates from Kent Peninsula. Laboratory codes are for the UCIAMS dates, and Borden codes are the site designations. Value in last column is the area under the probability distribution for the calibrated age range.

\begin{tabular}{|c|c|c|c|c|c|c|}
\hline Lab Code & Borden Code & Material & Elevation (m asl) & ${ }^{14} \mathrm{C}$ Age $\left(\delta^{13} \mathrm{C}\right)$ & Calib 5.0.2 2-Sigma Range BP & Area \\
\hline 30328 & NfNg-27-F2 & Salix charcoal & 45.5 & $1750 \pm 15$ & $1612-1709$ & 1 \\
\hline 30360 & NfNg-27-F1 & Salix charcoal & 45.5 & $1745 \pm 15$ & $1607-1709$ & 1 \\
\hline 29241 & NfNh-10-F1 & Caribou or muskox bone & 43 & $3680 \pm 20(-16.8)$ & $3967-4086$ & 0.954 \\
\hline 30359 & NfNg-17 & Salix charcoal & 40.5 & $4070 \pm 15$ & $4517-4583$ & 0.814 \\
\hline 30358 & NfNg-9-F4 & Salix charcoal & 37.5 & $4415 \pm 20$ & $4950-5047$ & 0.762 \\
\hline 30363 & NfNf-10-F1 & Salix charcoal & 33 & $3925 \pm 15$ & $4347-4422$ & 0.696 \\
\hline 30433 & NeNi-4 & Picea charcoal & 32.5 & $3405 \pm 15$ & $3613-3696$ & 0.987 \\
\hline 30366 & NfNh-4 & Salix charcoal & 31.5 & $3695 \pm 15$ & $3982-4086$ & 1.000 \\
\hline 30365 & NfNh-3-F2 & Salix charcoal & 31 & $3910 \pm 15$ & $4293-4418$ & 1.000 \\
\hline 30356 & NfNg-6-F1 & Salix charcoal & 30.5 & $3960 \pm 15$ & $4409-4444$ & 0.770 \\
\hline 30357 & $\mathrm{NfNg}-7-\mathrm{F} 4$ & Salix charcoal & 29.5 & $3775 \pm 15$ & $4089-4161$ & 0.753 \\
\hline 30381 & NfNh-6-F25 & Picea charcoal & 29 & $3955 \pm 15$ & $4404-4445$ & 0.827 \\
\hline 30361 & NfNf-7 & Salix charcoal & 24 & $3025 \pm 20$ & $3201-3274$ & 0.633 \\
\hline 30364 & NfNh-2-F1 & Salix charcoal & 22 & $2465 \pm 20$ & $2449-2618$ & 0.582 \\
\hline 30362 & NfNf-8-F1 & Salix charcoal & 18.5 & $2690 \pm 15$ & $2756-2799$ & 0.797 \\
\hline 30380 & NfNf-12-F1 & Picea wood & 15 & $2025 \pm 15$ & $1927-2003$ & 0.987 \\
\hline 29157 & NfNg-30 & Burnt moss Dicranum sp. & 8 & $1460 \pm 15(-26.7)$ & $1309-1379$ & 1.000 \\
\hline 29156 & NfNg-15-F1 & Burnt moss Dicranum sp. & 8 & $1480 \pm 15(-26.3)$ & $1327-1400$ & 1.000 \\
\hline 29155 & NfNg-14-F5 & Burnt moss Dicranum sp. & 7 & $1465 \pm 15(-26.2)$ & $1311-1383$ & 1.000 \\
\hline 29158 & NeNi-5 & Burnt moss Dicranum sp. & 6.5 & $1430 \pm 20(-26.2)$ & $1296-1356$ & 1.000 \\
\hline
\end{tabular}

because datable materials were more readily available from them. Their ages range from $2000 \pm 15$ to $865 \pm 15^{14} \mathrm{C}$ years BP. The two determinations that are less than $1000 \mathrm{BP}$ are both maximum-limiting dates on Picea charcoal. The architecture of these features is discussed below.

Surface artefacts, mainly microblades and rare endblades of chert, are too rare to confirm or deny these cultural assignments. Clearly, however, the similar patterns of strong clustering of sites by elevation in all three survey areas suggest discrete occupation intervals and perhaps intervals of abandonment.

\section{Common Dwelling Types}

We recognized six common types of Paleoeskimo occupation features in the two regions surveyed (Table 4). On the Kent Peninsula, the most abundant of these types is the midpassage lacking associated tent ring, which comprises $51 \%$ of features (Fig. 4a). Next most common are tent rings with midpassages (Fig. 4b) and tent rings lacking midpassages, each comprising $12 \%$ of features. Paved areas (Fig. 4c) are nearly as common as each type of tent ring, and are more common if paved areas with midpassages are included. Isolated hearths $(7 \%)$-isolated in the sense that they are not contained within the preserved outline of a larger dwelling feature - are the remaining common type of dwelling feature on the Kent Peninsula and are generally box hearths made of vertical (or formerly vertical) flagstones (Fig. 4d).

On King William Island, in contrast, the most common dwelling type is the simple tent ring (28\%; Fig. 5a), with the midpassage (lacking tent ring), the tent ring with midpassage (Fig. 5b), and the paved area being almost equally common at $20 \%, 18 \%$, and $17 \%$, respectively. Isolated hearths, again mainly box hearths, comprise $11 \%$ of features here. The most amorphous Paleoeskimo dwelling type, the "sod patch," was not seen on the Kent Peninsula and is evidently rare on King William Island although it is relatively common on the western Boothia Peninsula ( $8 \%$; Savelle and Dyke, in press) and elsewhere. Otherwise, the proportions of dwelling types on King William Island closely resemble those reported by us from the western Boothia Peninsula.

Tent rings are most commonly rectangular (includes square) on both the Kent Peninsula and King William Island, though circular to oval forms are more common in the latter than in the former region. Most dwelling feature types occur across the elevation span of occupied sites and hence lack any temporal significance within the Paleoeskimo sequence. Tent rings with distinct central hearths may be restricted to early Pre-Dorset, as they apparently are on western Boothia Peninsula; however, these are relatively uncommon dwelling types.

Within multi-dwelling sites, it is fairly common to find that all features have the same architecture for sites of eight dwellings and less, but it is considerably more common that there are features of different architecture in these smaller sites. No sites with more than eight dwellings display homogeneity of dwelling type (Table 5). Within the 10 sites on the Kent Peninsula that have homogeneous dwelling types, most are midpassages without tent rings, whereas sites with homogeneous features on King William Island are distributed amongst the dwelling styles.

\section{Uncommon Dwelling Features}

In the North American Arctic, two of the more striking Paleoeskimo dwelling features are the Dorset longhouse, which attains lengths of over $40 \mathrm{~m}$ (Damkjar, 2000), and the Dorset winter house, a shallowly excavated feature. We found no longhouses or winter houses on the Kent Peninsula or on King William Island, though at one site on the Kent Peninsula, Dorset tent floors were shallowly, but conspicuously, excavated. 
TABLE 3. Radiocarbon dates from King William Island. Laboratory codes are for UCIAMS dates, and Borden codes are the site designations. Dates marked with asterisk result from burning of ancient driftwood. Value in last column is the area under the probability distribution for the calibrated age range.

\begin{tabular}{|c|c|c|c|c|c|c|}
\hline Lab Code & Borden Code & Material & Elevation (m asl) & ${ }^{14} \mathrm{C}$ Age $\left(\delta^{13} \mathrm{C}\right)$ & Calib 5.0.2 2-Sigma Range BP & Area \\
\hline \multicolumn{7}{|c|}{ Peel Inlet area: } \\
\hline 30370 & NiLa-12 & Burnt Salix bark & 33.5 & $3785 \pm 15$ & $4091-4235$ & 1.000 \\
\hline 30442 & NhLa-31-F2 & Picea charcoal & 31.5 & $3945 \pm 15$ & $4387-4439$ & 0.807 \\
\hline 30440 & NiLa-8 & Picea charcoal & 31.5 & $3770 \pm 15$ & $4087-4159$ & 0.842 \\
\hline 29243 & NiLa-9-F1 & Caribou or muskox bone & 31.5 & $3720 \pm 20(-17.9)$ & $3985-4099$ & 0.810 \\
\hline 30441 & NhLa-25 & Picea charcoal & 31 & $3610 \pm 15$ & $3868-3974$ & 1.000 \\
\hline 30367 & NhLa-14-F1 & Burnt Salix bark & 29.5 & $4100 \pm 15$ & $4527-4629$ & 0.721 \\
\hline 30434 & NhLa-1-F2 & Picea charcoal & 29.5 & $3555 \pm 15$ & $3827-3898$ & 0.955 \\
\hline 30437 & NhLa-16 & Picea charcoal & 29 & $5990 \pm 20 *$ & $6777-6891$ & 0.962 \\
\hline 30439 & NiLa-6-F1 & Picea charcoal & 28 & $3490 \pm 15$ & $3704-3829$ & 1.000 \\
\hline 29244 & NhLa-23-F2 & Caribou or muskox bone & 28 & $3640 \pm 15(-17.6)$ & $3897-3985$ & 0.961 \\
\hline 30436 & NhLa-13-F14 & Picea charcoal & 27.5 & $4335 \pm 20$ & $4850-4961$ & 1.000 \\
\hline 30438 & NiLa-3-F1 & Picea charcoal & 25.5 & $3450 \pm 15$ & $3641-3824$ & 1.000 \\
\hline 30435 & NhLa-8-F3 & Picea charcoal & 16 & $2895 \pm 15$ & $2960-3077$ & 1.000 \\
\hline 30448 & NhLa-5 & Caribou or muskox bone & 15.5 & $1850 \pm 15(-18.4)$ & $1720-1825$ & 0.976 \\
\hline 30368 & NhLa-19 & Burnt Salix bark & 12 & $2000 \pm 15$ & $1920-1992$ & 0.913 \\
\hline 29242 & NhLa-7-F10 & mammal longbone & 11 & $2685 \pm 15(-15.4)$ & $2754-2797$ & 0.870 \\
\hline 30369 & NiLb-1 & Burnt Salix bark & 6 & $1280 \pm 15$ & $1178-1275$ & 1.000 \\
\hline \multicolumn{7}{|c|}{ Cape Jane Franklin: } \\
\hline 30317 & NjLg-12 & Picea charcoal & 44.5 & $4170 \pm 15$ & $4627-4826$ & 1.000 \\
\hline 29245 & NjLg-19-F3 & mammal longbone & 33 & $4370 \pm 20(-14.5)$ & $4863-4974$ & 0.972 \\
\hline 30325 & NjLg-39-F1 & Picea charcoal & 31 & $5505 \pm 25^{*}$ & $6276-6323$ & 0.861 \\
\hline 30444 & $\mathrm{NjLg}-8$ & Picea charcoal & 30 & $3830 \pm 20$ & $4150-4296$ & 0.974 \\
\hline 30324 & $\mathrm{NjLg}-38$ & Picea charcoal & 28.5 & $4475 \pm 20$ & $5038-5283$ & 0.963 \\
\hline 30326 & NjLg-40-F2 & Picea charcoal & 28 & $4190 \pm 20$ & $4643-4838$ & 0.994 \\
\hline 30318 & NjLg-11-F13 & Picea charcoal & 28 & $4015 \pm 20$ & $4427-4523$ & 1.000 \\
\hline 30316 & NjLg-11 & Picea charcoal & 28 & $3880 \pm 15$ & $4280-4408$ & 0.832 \\
\hline 30371 & $\mathrm{NjLg}-25-\mathrm{F} 2$ & Salix charcoal & 27.75 & $4195 \pm 15$ & $4702-4758$ & 0.629 \\
\hline 30372 & NjLg-33-F6 & Salix charcoal & 27.5 & $4110 \pm 15$ & $4530-4805$ & 1.000 \\
\hline 30320 & NjLg-22-F1 & Picea charcoal & 27 & $4145 \pm 15$ & $4606-4729$ & 0.653 \\
\hline 30443 & NjLg-7-F9 & Picea charcoal & 26.5 & $4610 \pm 15$ & $5305-5442$ & 1.000 \\
\hline 29246 & $\mathrm{NjLg}-36-\mathrm{F} 8$ & mammal longbone & 25.5 & $4175 \pm 20(-14.4)$ & $4627-4763$ & 0.804 \\
\hline 30321 & NjLg-24-F1 & Picea charcoal & 23 & $3760 \pm 20$ & $4081-4160$ & 0.845 \\
\hline 30327 & NjLg-31-F1 & Picea charcoal & 18 & $3440 \pm 20$ & $3637-3727$ & 0.835 \\
\hline 30373 & NjLg-41-F1 & Salix charcoal & 13.5 & $1320 \pm 15$ & $1255-1293$ & 0.848 \\
\hline 30382 & NjLg-29-F2 & Salix charcoal & 12 & $2105 \pm 15$ & $2036-2133$ & 0.891 \\
\hline 30322 & NkLg-16 & Picea charcoal & 7.5 & $995 \pm 15$ & $907-956$ & 0.959 \\
\hline 30323 & NkLg-18 & Picea charcoal & 7.5 & $865 \pm 15$ & $733-792$ & 1.000 \\
\hline 29160 & NkLg-17-F1 & Burnt moss Dicranum sp. & 7 & $1260 \pm 15(-24.6)$ & $1174-1264$ & 1.000 \\
\hline 29159 & $\mathrm{NjLg}-21$ & Burnt moss Dicranum sp. & 6 & $1495 \pm 20(-21.2)$ & $1334-1410$ & 1.000 \\
\hline 30319 & NkLg-15-F1 & Picea charcoal & 5 & $1025 \pm 20$ & $922-964$ & 1.000 \\
\hline
\end{tabular}

Nevertheless, three Dorset features on King William Island are of exceptional size and were probably multi-family dwellings. Two are at single-dwelling sites. Site 06-98 (NhLa-5) is a $6.9 \mathrm{~m}$ long, $7.5 \mathrm{~m}$ wide, heavy flagstone tent ring at $15.5 \mathrm{~m}$ elevation (Fig. 6a). A $1.2 \mathrm{~m}$ midpassage runs along the length, which is unusually oriented along beach strike, possibly to accommodate the building size. The interior is further partitioned by lines of heavy stones, which may have separated living areas. A caribou or muskox long bone fragment from beneath a stone in this feature dated $1850 \pm 15{ }^{14} \mathrm{C}$ years BP (UCIAMS-30448). Site 06-112 (NhLa-19; Fig. 6b) at $12 \mathrm{~m}$ elevation is an exceptionally long $(7.1 \mathrm{~m})$ midpassage with two apparent hearth areas. Salix charcoal (bark) from a hearth dated at $2000 \pm 15{ }^{14} \mathrm{C}$ years BP (UCIAMS-30368). While not longhouses in the classic Late Dorset sense, these large features are nevertheless within the earliest period of longhouse development noted by Damkjar (2000). If they are multi-family aggregation features, they may represent early expressions of what later became the classic Late Dorset longhouse.

We previously reported that Late Dorset midpassages on western Boothia Peninsula stand out as architecturally distinct from older midpassages in the same region (Savelle and Dyke, in press). We recorded several additional Late Dorset midpassages on King William Island that are of the Boothia type, though not all Late Dorset dwelling features there are of that type. Although we included them in the statistical summary of common features above, they warrant a brief additional description, because they are rare, having been recorded outside of our study area only in northwest Greenland (J. Darwent and C. Darwent, pers. comm. 2008). They are found only in the narrow, lower range of Paleoeskimo dwellings around $4-8 \mathrm{~m}$ elevation, and most are well preserved (Fig. 7). All observed features occur without associated tent rings, though some are within prepared floor areas. All have one end much narrower than the other, the two rows 
TABLE 4. Types of Paleoeskimo occupation features. Elevations are in metres above high tide.

\begin{tabular}{lccc}
\hline \hline Feature Type & Abundance & Elevation & Age Range \\
\hline Kent Peninsula: & & & \\
Tent ring & $27(12 \%)$ & $7-48.5$ & Late Dorset-early Pre-Dorset \\
Tent ring with hearth & $2(1 \%)$ & $29.5-33$ & Early Pre-Dorset \\
Tent ring with midpassage & $27(12 \%)$ & $7-45.5$ & Late Dorset-early Pre-Dorset \\
Midpassage without tent ring & $111(51 \%)$ & $6.5-43$ & Late Dorset-early Pre-Dorset \\
Paved area & $25(11 \%)$ & $7-48.5$ & Late Dorset-early Pre-Dorset \\
Paved area with midpassage & $12(5 \%)$ & $15-30$ & Late Pre-Dorset \\
Sod patch & 0 & & Dorset-early Pre-Dorset \\
Isolated hearth & $15(7 \%)$ & $12-43(45)$ & \\
& & & \\
King William Island: & $91(28 \%)$ & $11-33$ & Dorset-early Pre-Dorset \\
Tent ring & $17(5 \%)$ & $12-33.5$ & Dorset-early Pre-Dorset \\
Tent ring with hearth & $58(18 \%)$ & $6-44$ & Late Dorset-early Pre-Dorset \\
Tent ring with midpassage & $66(20 \%)$ & $5-44.5$ & Late Dorset-early Pre-Dorset \\
Midpassage without tent ring & $54(17 \%)$ & $5-36$ & Late Dorset-early Pre-Dorset \\
Paved area & 1 & 17 & Late Pre-Dorset \\
Paved area with midpassage & $2(1 \%)$ & $23.5-25.5$ & Early Pre-Dorset \\
Sod patch & $37(11 \%)$ & $5-35.5$ & Late Dorset-early Pre-Dorset \\
Isolated hearth & & & \\
\hline \hline
\end{tabular}
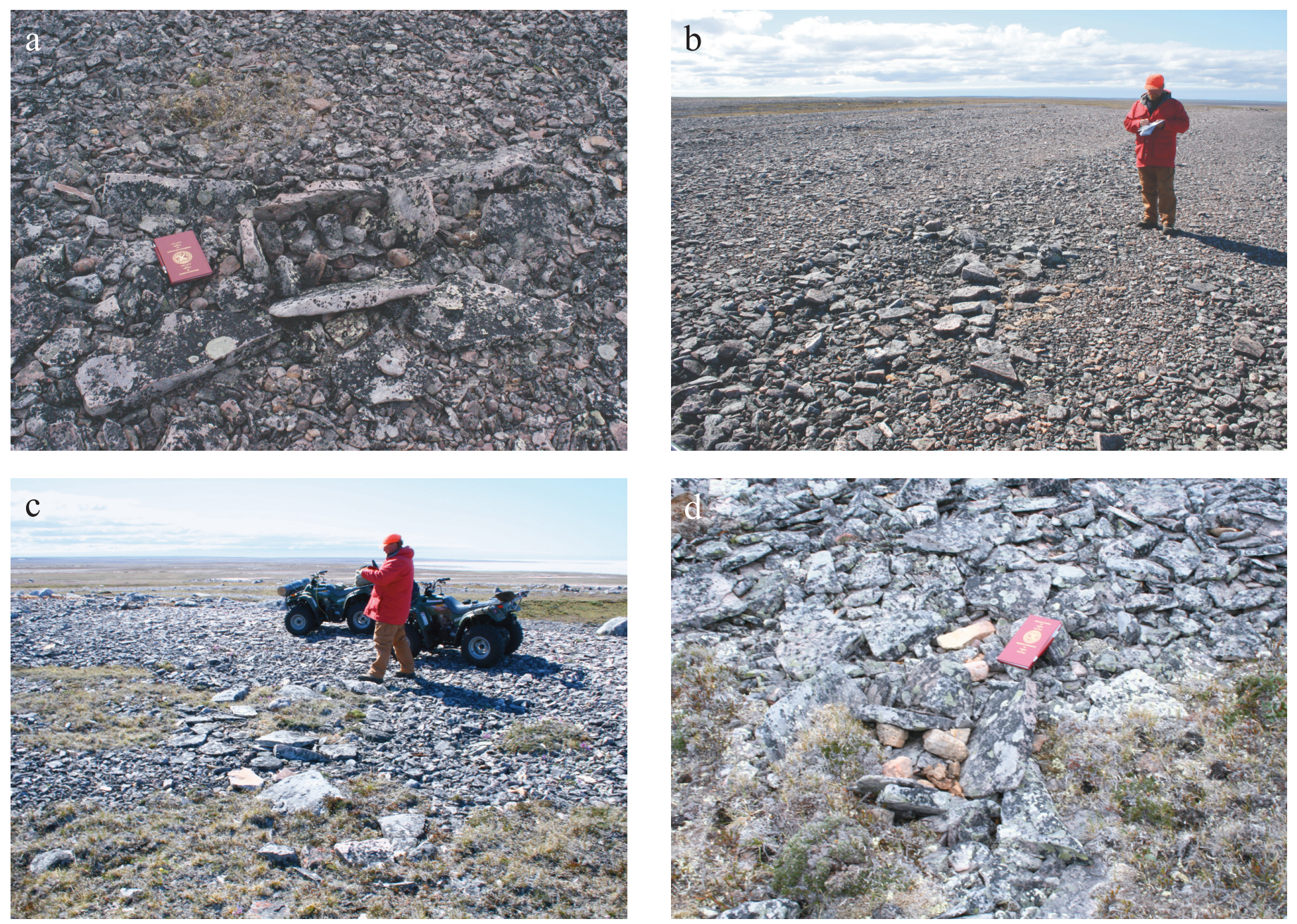

FIG. 4. (a) Midpassage with central box hearth at $31 \mathrm{~m}$ elevation, Kent Peninsula, site 06-54-F2 (NfNh-3-F2). Salix charcoal from this hearth dated $3910 \pm 15$ BP (UCIAMS-30365). (b) Midpassage (parallel to beach ridge) in a tent ring at $43 \mathrm{~m}$ elevation, Kent Peninsula, site 06-61-F1 (NfNh-10-F1). A terrestrial mammal longbone from the midpassage dated $3680 \pm 20$ BP (UCIAMS-29241). (c) Rectangular paved area at $18 \mathrm{~m}$ elevation, Kent Peninsula, site 06-63 (NfNh-12). (d) Box hearth at 31.5 m elevation, Kent Peninsula, site 06-55 (NfNh-4). Salix charcoal dated $3695 \pm 15$ BP (UCIAMS-30366).

of side stones converging so as to resemble a slender arrowhead. That effect in some features is exaggerated by one side being shortened but converging fully with the longer one near mid-section, forming a lower case "y." Most have still-erect 
TABLE 5. Range of dwelling types according to site size. Homogeneity value in the last column is the percentage of total sites for each size that have only one type of dwelling.

\begin{tabular}{|c|c|c|c|c|c|c|c|c|}
\hline Dwellings per Site & 1 Type & 2 Types & 3 Types & 4 Types & 5 Types & 6 Types & Sum & Homogeneity \\
\hline \multicolumn{9}{|l|}{ Kent Peninsula: } \\
\hline 2 & 3 & 11 & & & & & 14 & 21 \\
\hline 3 & 1 & 4 & 2 & & & & 7 & 14 \\
\hline 4 & 2 & 4 & & & & & 6 & 33 \\
\hline 5 & 2 & & & 1 & & & 3 & 67 \\
\hline 6 & 1 & & & & & & 1 & 100 \\
\hline 8 & 1 & & & 1 & & & 2 & 50 \\
\hline 10 & & 2 & & & & & 2 & 0 \\
\hline 26 & & & 1 & & & & 1 & 0 \\
\hline 27 & & & & 1 & & & 1 & 0 \\
\hline \multicolumn{9}{|l|}{ King William Island: } \\
\hline 2 & 7 & 7 & & & & & 14 & 50 \\
\hline 3 & 2 & 11 & 3 & & & & 16 & 13 \\
\hline 4 & 2 & 4 & 4 & & & & 10 & 20 \\
\hline 5 & & 1 & & & & & 1 & 0 \\
\hline 6 & & & 2 & & & & 2 & 0 \\
\hline 7 & & & 1 & & & & 1 & 0 \\
\hline 9 & & 1 & & 2 & 1 & & 4 & 0 \\
\hline 10 & & & & & 1 & & 1 & 0 \\
\hline 11 & & & & 1 & & & 1 & 0 \\
\hline 12 & & 1 & 1 & & & & 2 & 0 \\
\hline 14 & & & & 1 & & & 1 & 0 \\
\hline 15 & & & & 1 & & & 1 & 0 \\
\hline 18 & & & & 1 & & & 1 & 0 \\
\hline 20 & & & & & & 1 & 1 & 0 \\
\hline
\end{tabular}

lamp stands, usually one and rarely two, and these stands are adjacent to heavy, flat, stone slabs that may have served as meat-cutting surfaces. We encountered these features at sites 06-95 (NhLa-2), -172 (NjLg-21), -185 (NkLg-16), -186 (NkLg-17), and -190 (NkLg-19). One site has two features; the others occur alone, typically on small points of land. No Late Dorset midpassages of this exact type were seen on the Kent Peninsula. However, Late Dorset midpassages there (Fig. 8) contain similar lamp stands associated with possible cutting stones, and one had a soapstone lamp fragment in the midpassage. In both regions, burnt moss is common (and almost exclusively found) in these Late Dorset features. Radiocarbon dates on moss are listed in Table 2.

\section{Social Dynamics Based on Number of Features per Site}

In this section we draw inferences about Paleoeskimo societies based on site sizes, with "size" defined as the number of dwelling features at a site. Of the 73 sites that we recorded on the Kent Peninsula, 36 (49\%) are single-dwelling features, $14(19 \%)$ have two dwellings, $7(10 \%)$ have three dwellings, $6(8 \%)$ have four dwellings, $3(4 \%)$ have five dwellings, $1(1 \%)$ has six dwellings, and $6(8 \%)$ have more than six dwellings. Very large sites are rare, but the largest has 27 dwellings (Fig. 9; Table 5). Similarly, of the 95 sites that we recorded on King William Island, 39 (41\%) are single dwelling features, 14 (15\%) have two dwellings, $16(17 \%)$ have three dwellings, $10(11 \%)$ have four dwellings, and $1(1 \%)$ has five dwellings. The remaining 15 sites $(20 \%)$ have more than six dwellings, and the largest has 20 dwellings (Fig. 9; Table 5). These distributions seem to accord well with previous general observations of Paleoeskimo site characteristics, and they are very similar to the distribution we reported from western Boothia Peninsula.

Although there are no descendents of Paleoeskimo populations, we suggest, on the basis of ethnographic analogy and following others (e.g., McGhee, 1996), that for most of the year, single families, or groups of two or three families lived and hunted together, probably moving frequently. The larger sites, on the other hand, and those with exceptionally large individual features, are most likely the result of seasonal band aggregations (see below). Larger sites are especially evident on the early Pre-Dorset beach levels in both regions, and on the Kent Peninsula they are clustered on various levels of a single promontory.

The question of contemporaneity at dual- or multi-dwelling sites is important, especially at the larger sites. It is impossible to prove by direct dating. Other methods, such as intra-site refitting studies, could contribute in this regard (see e.g., Hofman and Enloe, 1992; Waguespack, 2002), but such studies are beyond the scope of our work. Nevertheless, we observed no evidence of scavenging of structural stones or of overlap of dwellings that might indicate reoccupation of sites. More importantly, given that nearly all ethnographically recorded hunter-gatherer groups exhibit periodic fission-fusion behaviour (e.g., Binford, 1980, 1982; Kelly, 1983, 1995), the only available evidence of band aggregations, in the absence of large communal structures, will be sites with large numbers of dwellings. Although the various types of dwellings at large sites may indicate occupations during different seasons (and hence not strictly synchronous), we are not aware of any studies that demonstrate 

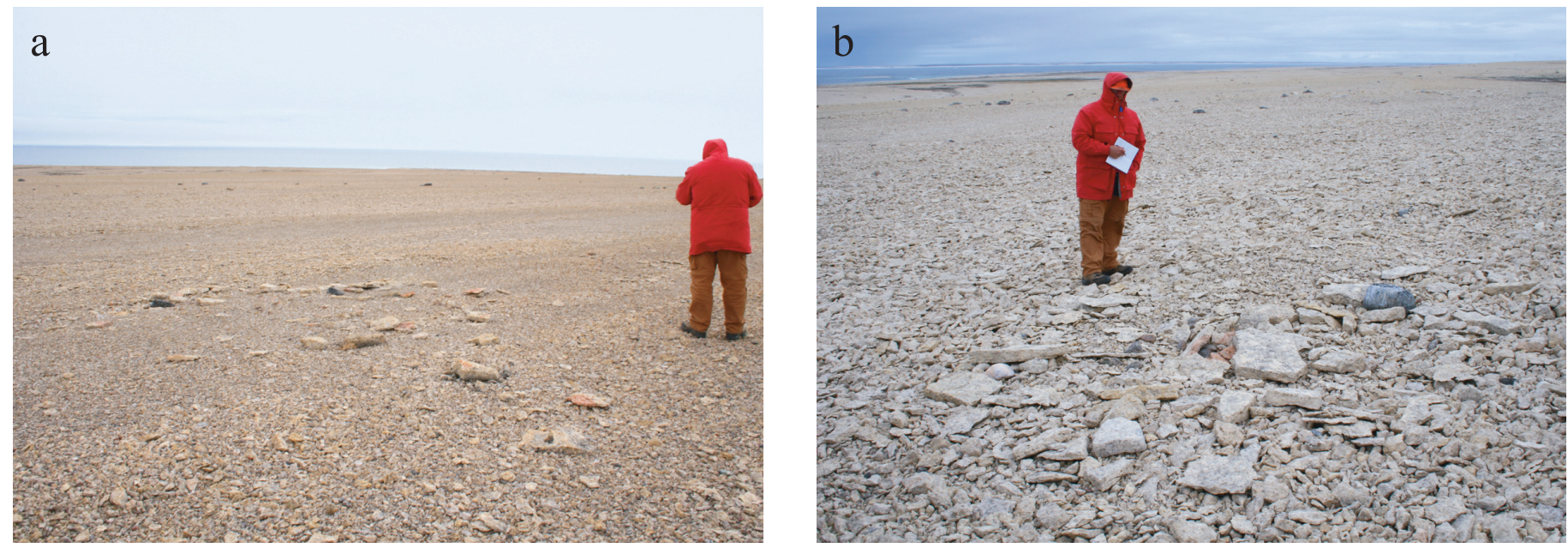

FIG. 5. (a) Simple tent ring at $27.5 \mathrm{~m}$ elevation, north of Peel Inlet, King William Island, site 06-106-F1 (NhLa-13-F1). Picea charcoal from F14 (a box hearth) at this site dated $4335 \pm 20$ BP (UCIAMS-30436). (b) Tent ring with midpassage at 29 m elevation north of Peel Inlet, King William Island, site 06-109 (NhLa-16). Picea charcoal from the midpassage dated $5990 \pm 20$ BP (UCIAMS-30437), an aberrant age due to burning of ancient driftwood.
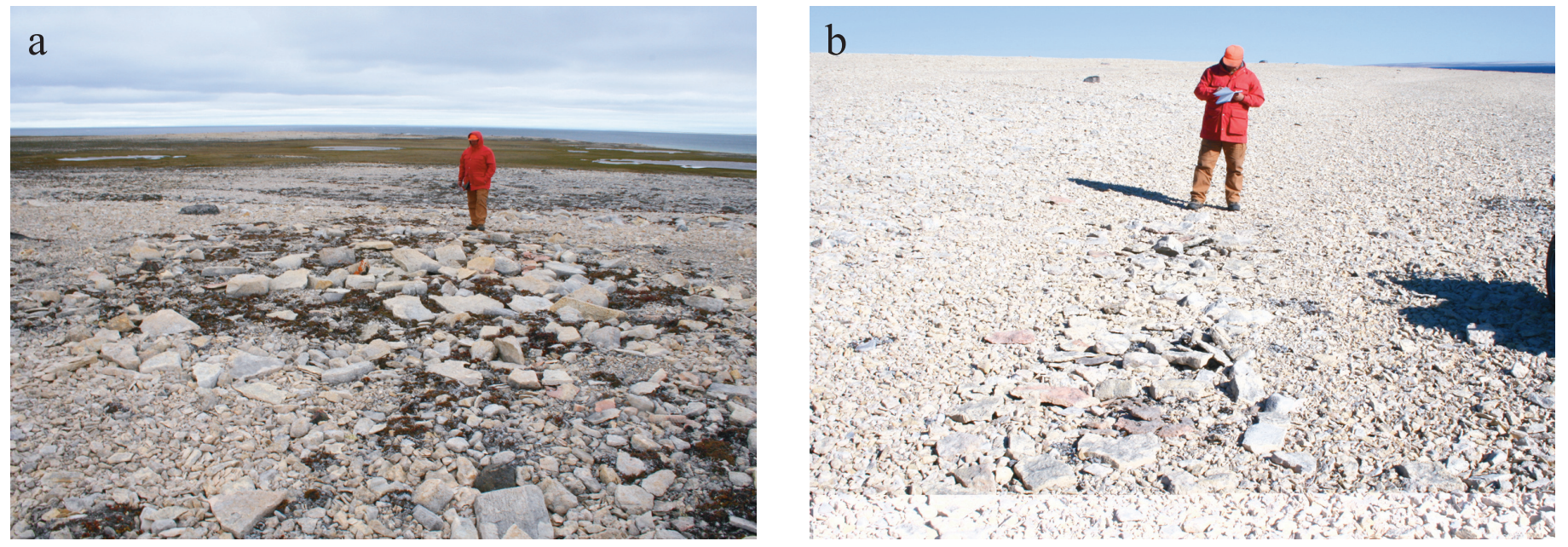

FIG. 6. Exceptionally large Dorset features, King William Island. (a) site 06-98 (NhLa-5) at $15.5 \mathrm{~m}$ elevation. Caribou or muskox bone from this feature dated $1850 \pm 15$ BP (UCIAMS-30448). (b) site 06-112 (NhLa-19) at $12 \mathrm{~m}$ elevation. Burnt Salix bark from this feature dated $2000 \pm 15$ BP (UCIAMS-30368).
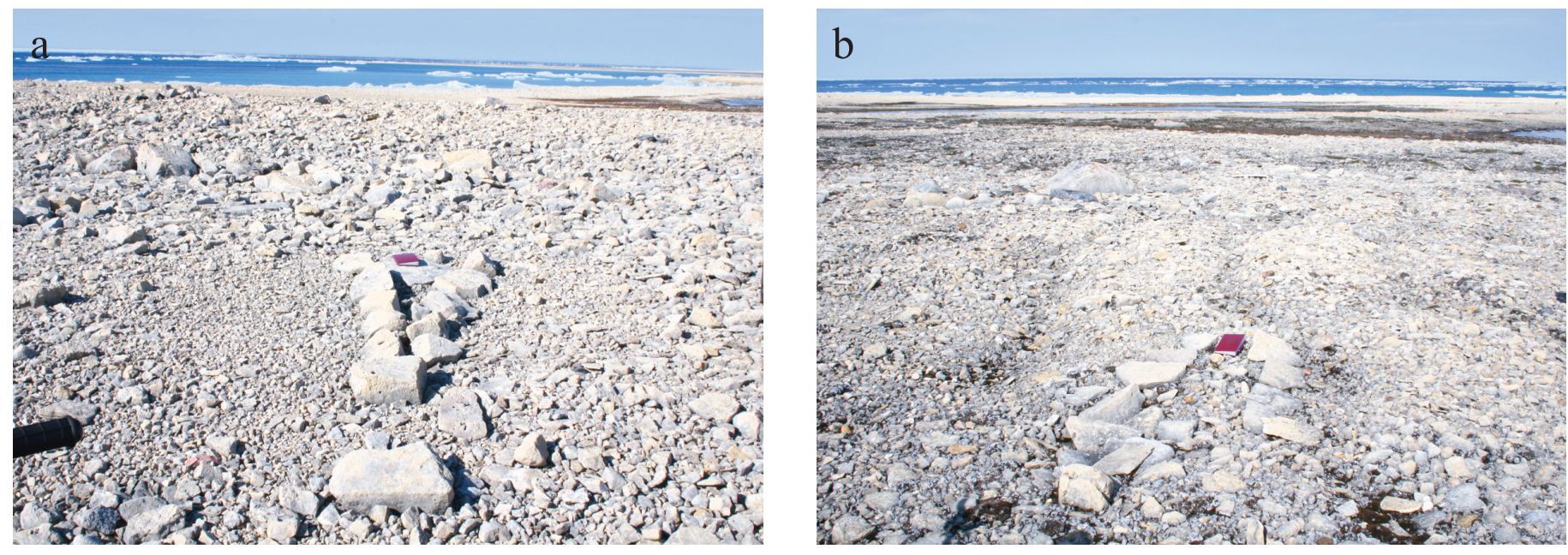

FIG. 7. Late Dorset midpassages of the "Boothia" (pointy) type in the Cape Jane Franklin area, King William Island. (a) Site 06-190 (NkLg-19) at 5 m elevation. (b) Site 06-186-F1 (NkLg-17-F1) at 7 m elevation. Most of the stones in this feature have fallen outward. Burnt moss from 06-186 dated $1260 \pm 15$ BP (UCIAMS29160). 

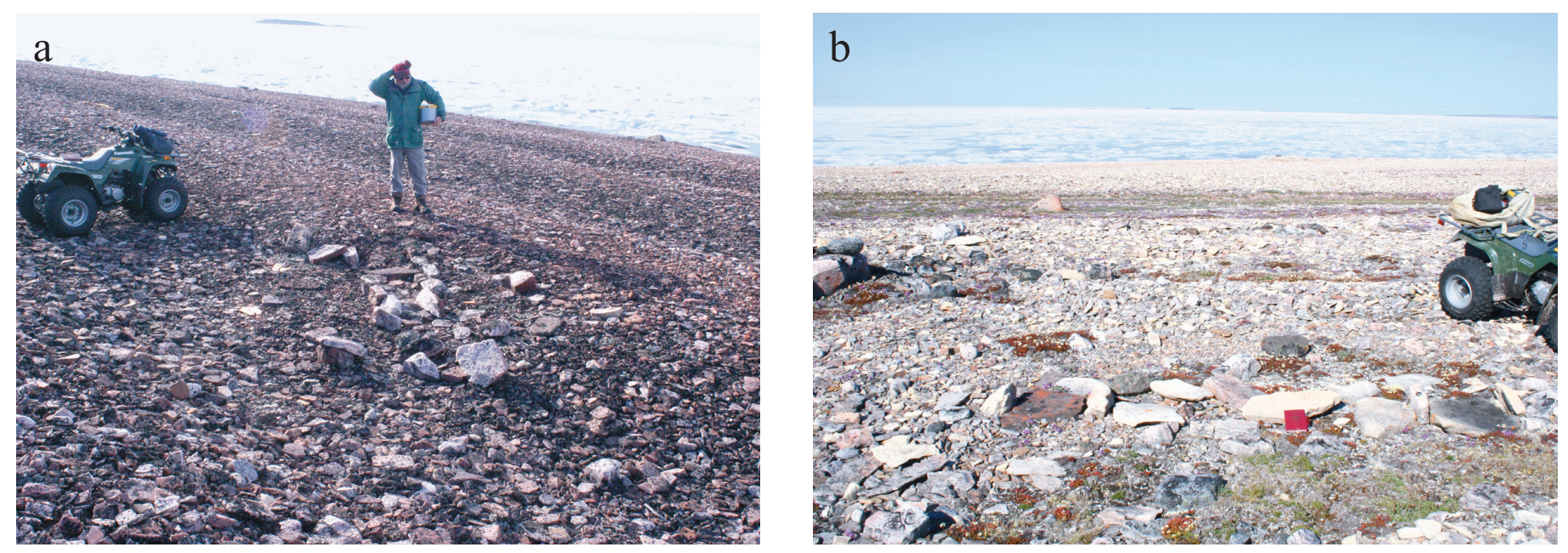

FIG. 8. Late Dorset midpassages on the Kent Peninsula: (a) Site 06-32 (NfNg-30) at $8 \mathrm{~m}$ elevation in a prepared floor area. Burnt moss from this feature dated $1460 \pm 15$ BP (UCIAMS-29157). (b) Site 06-70 (NeNi-5) at $6.5 \mathrm{~m}$ elevation. Note lamp stands at each end. Burnt moss from this feature dated $1430 \pm 20 \mathrm{BP}$ (UCIAMS-29158).

Kent Peninsula Sites $(n=73)$
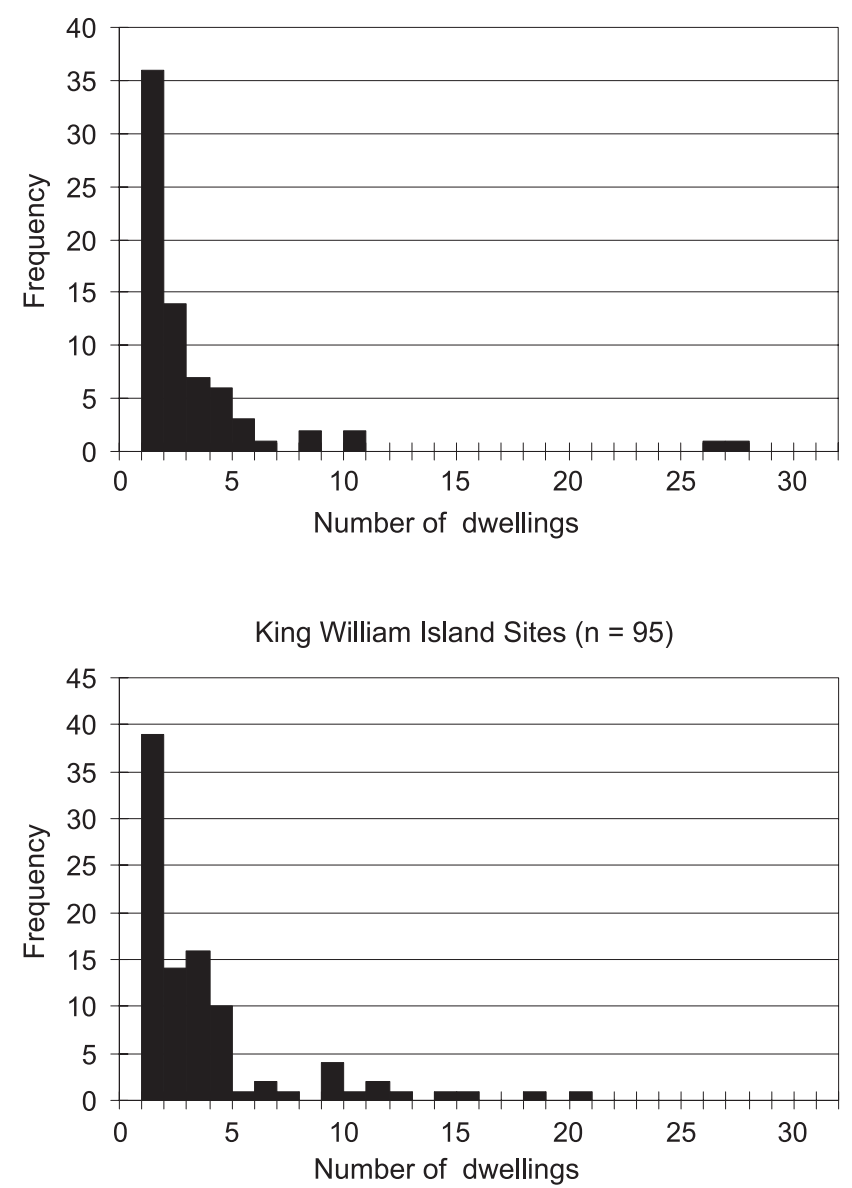

FIG. 9. Sizes of Paleoeskimo sites on the Kent Peninsula and King William Island, as measured by the number of dwelling features per site. Note different y-axis scales.

that, for example, tents with hearths and tents with midpassages could not have been occupied simultaneously. However, this is clearly an issue that needs attention.
While admitting uncertainty, we believe that the patterns of site sizes recorded in the survey areas are consistent with periodic fission-fusion patterns. Thus we suggest that many, but not necessarily all, dwellings at larger sites were occupied simultaneously. We are not assuming contemporaneity, but rather emphasizing that the site size patterns, together with the lack of evidence of feature overlap and scavenging, are consistent with fission-fusion cycles. The alternative theory, in the absence of more tangible evidence such as large communal structures, is that much Paleoeskimo social behaviour did not involve fission-fusion cycles, and thus this group was logistically different from any other known hunter-gatherer society. This alternative is highly unlikely from an anthropological perspective, and we are not aware of any archaeological evidence in support of it. Indeed, as noted by McGhee (1996:123), "The basic organization of [historic] Inuit society serves as the best available model on which to reconstruct the social organization of the Paleo-Eskimos."

That being so, the largest bands recorded in our survey may have consisted of up to 27 families on the Kent Peninsula and up to 20 families on King William Island, but aggregations of 5-15 families were apparently more typical. Still larger gatherings may have occurred outside of the areas surveyed. Family aggregations of up to 27 or so are consistent with our previous data from the Boothia Peninsula and with historical Inuit groups sharing similar environments. For example, maximal band aggregations amongst the Netsilik Inuit of southern Boothia Peninsula averaged 100 people (Damas, 1969; Balikci, 1984). Amongst the Copper Inuit of Victoria Island and the mainland coast west of the Kent Peninsula, maximal band aggregations also averaged about 100 people, with the largest recorded being 150-166 (Damas, 1984). The number of occupants of each dwelling structure would have varied (for example, amongst the historic Caribou Inuit, family size varied from 2 to 9; Birket-Smith, 1929:67-68). However, if average nuclear family size was similar to that of historic 
TABLE 6. Dimensions (m) of Paleoeskimo tent rings and midpassage dwellings, Kent Peninsula. SE: standard error; SD: standard deviation.

\begin{tabular}{|c|c|c|c|c|c|}
\hline Parameter & Mean & $\mathrm{SE}$ & Median & Mode & SD \\
\hline Tent ring length & 2.74 & 0.10 & 2.70 & 3.10 & 0.77 \\
\hline Tent ring width & 2.94 & 0.14 & 2.60 & 2.20 & 1.03 \\
\hline Tent ring area & 8.54 & 0.69 & 7.36 & 5.50 & 5.15 \\
\hline Midpassage length & 2.36 & 0.04 & 2.30 & 2.10 & 0.54 \\
\hline Midpassage width & 0.82 & 0.02 & 0.80 & 0.80 & 0.23 \\
\hline Midpassage area & 1.96 & 0.06 & 1.76 & 1.52 & 0.78 \\
\hline Midpassage dwelling area & 8.40 & 0.29 & 7.56 & 6.31 & 3.58 \\
\hline Ratio TRW/MPL & 1.43 & 0.09 & 1.38 & 1.38 & 0.47 \\
\hline
\end{tabular}

TABLE 7. Dimensions (m) of Paleoeskimo tent rings and midpassage dwellings, King William Island.

\begin{tabular}{|c|c|c|c|c|c|}
\hline Parameter & Mean & SE & Median & Mode & SD \\
\hline Tent ring length & 3.16 & 0.07 & 3.00 & 2.70 & 0.84 \\
\hline Tent ring width & 3.26 & 0.07 & 3.20 & 3.20 & 0.84 \\
\hline Tent ring area & 10.77 & 0.48 & 9.28 & 8.64 & 6.10 \\
\hline Midpassage length & 3.14 & 0.09 & 2.90 & 2.90 & 1.03 \\
\hline Midpassage width & 0.81 & 0.03 & 0.80 & 0.80 & 0.28 \\
\hline Midpassage area & 2.67 & 0.17 & 2.16 & 1.84 & 1.84 \\
\hline Midpassage dwelling area & 12.26 & 0.80 & 9.90 & 5.57 & 8.78 \\
\hline Ratio TRW/MPL & 1.15 & 0.03 & 1.13 & 1.13 & 0.24 \\
\hline
\end{tabular}

Central Arctic Inuit groups, e.g., 4.3 for Caribou Inuit (Birket-Smith, 1929:67-68) and 4.5 for Netsilik Inuit (Rasmussen, 1931:84-90), the presumed seasonal aggregations represented by the largest Paleoeskimo sites are well within the size of historic Inuit aggregations.

\section{Social Dynamics Based on Dwelling Size}

Because of excellent exposure and preservation, most dwelling feature sizes can be measured accurately. Detailed measurements for all features are given in Savelle and Dyke (2007). In Tables 6 and 7, the statistics for tent rings include those with midpassages. In tent rings with midpassages, the average ratio of tent-ring width to midpassage length (MPL) is 1.43 on the Kent Peninsula $(\mathrm{n}=27)$ and 1.15 on King William Island $(\mathrm{n}=54)$. Therefore, we calculate the area of a midpassage dwelling lacking a tent ring on Kent Peninsula to be MPL $\times 1.43(\mathrm{MPL})$ (Table 6). On King William Island, the area of a midpassage dwelling lacking a tent ring is MPL $\times 1.15($ MPL) $($ Table 7).

As mentioned above, we measured the outside dimensions of tent rings, but did not include peripheral rocks that seemed to have been displaced outward. Thus total areas include the areas of the peripheral hold-down stones. However, given the nature and size of the tent rings dealt with, (see e.g., Figs. 4b, 5a, 5b, 6), the extra included area is generally small. For example, comparing our measurement technique to that used by LeMoine (2003) for Feature 30 at the Tasiarulik Site on Little Cornwallis Island, her outline of what she considers the interior of the tent ring (LeMoine, 2003:124-125; see also LeMoine et al., 2003:264) at $4.5 \times$ $5 \mathrm{~m}$ would differ very little from what we would consider exterior measurements. Thus, at least at the field-survey level dealt with here, external vs. internal will have little bearing on our population estimates for individual dwellings, especially since our concern is with overall trends.

Paleoeskimo dwelling size may have been closely tailored to the number of occupants, because that would have conserved heat, maximized fuel efficiency, and minimized transport of building materials (skins and poles). In that view, the most interesting information potentially to be gathered from dwelling sizes is the number of people that might have occupied the dwellings, hence family (and extended family) sizes. While most Arctic archaeologists are comfortable with the idea that larger dwellings probably were inhabited by more people than were smaller dwellings, interpretations of the number of individuals associated with particular dwellings are usually avoided, and instead the number of "social units" are inferred (see e.g., various papers in LeBlanc et al., 2003). This approach is understandable, given that there will obviously be a range of family sizes within any one group of families. However, at least for early Paleoeskimo, these units are typically considered to have been composed of a small number of individuals. Again, using historic analogy, in this case the relatively mobile Caribou and Netsilik Inuit, social units of perhaps four to five individuals seem a reasonable estimate of the norm for Paleoeskimo social units. McGhee (1996:63), for example, illustrates a family of five occupying an Independence $1 \mathrm{dwelling}$. If we accept average minimal social units of four to five people, we can suggest trends in populations represented by individual feature size and, through total feature area at multi-dwelling sites, trends in overall site population.

First, however, we need to consider what proportions of individual dwellings were used for sleeping as opposed 
Tent Ring Areas, Kent Pen $(n=56)$

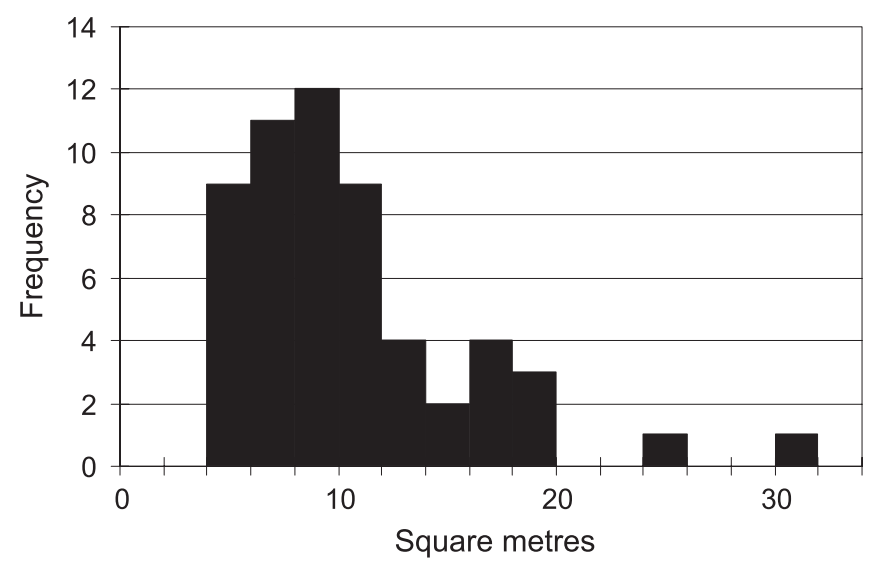

Tent Ring Areas, KWI $(n=163)$

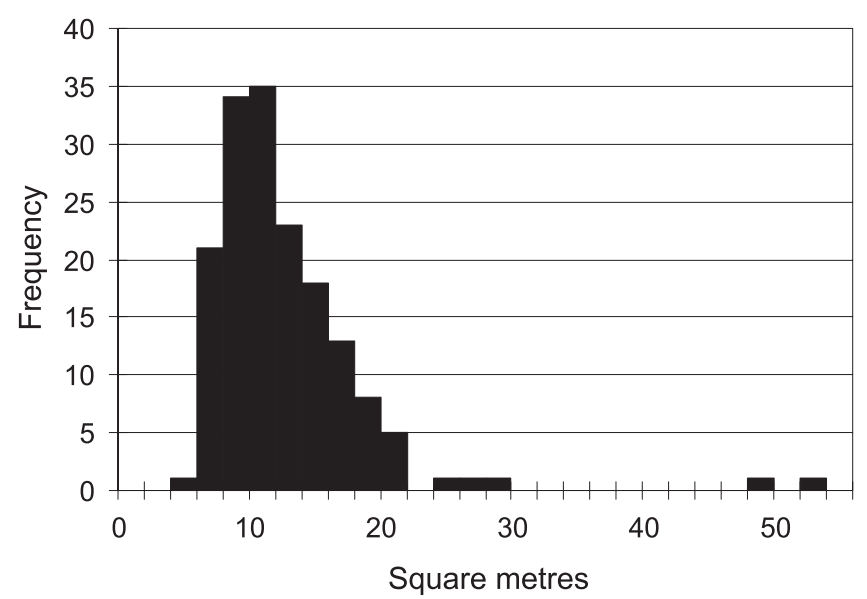

MP Dwelling Areas, Kent Pen $(n=150)$

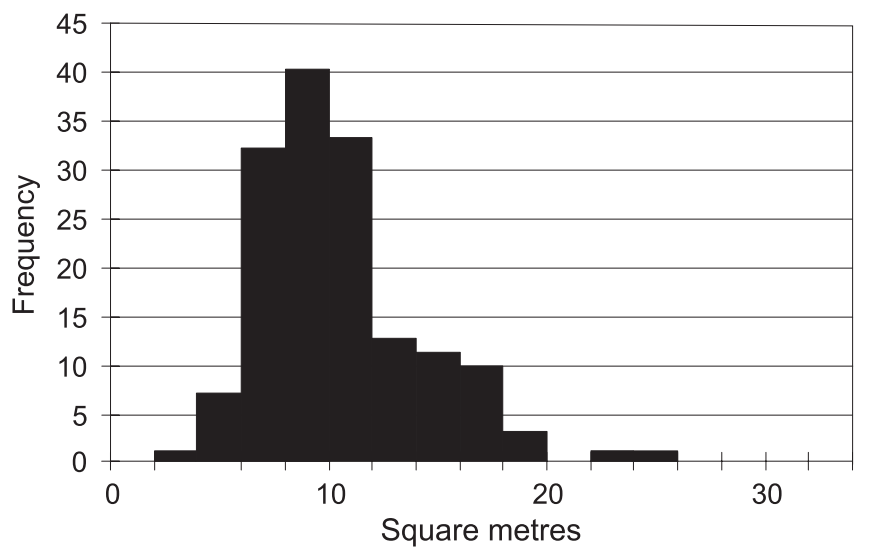

MP Dwelling Areas, KWI $(n=120)$

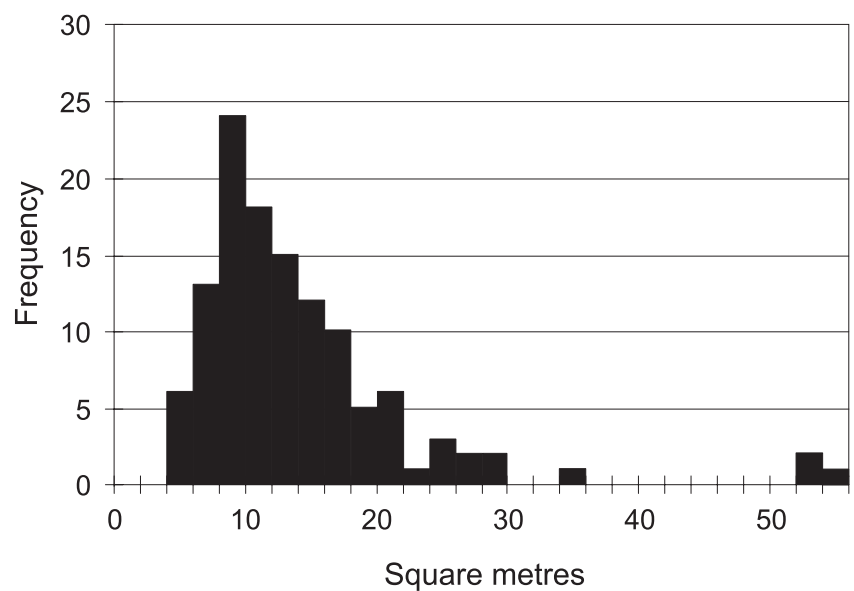

FIG. 10. Floor areas of tent rings and midpassage dwellings on Kent Peninsula and King William Island. Note different y-axis and x-axis scales.

to other activities. That proportion is typically not obvious for many Paleoeskimo dwellings in our study area, because sleeping areas are not defined. These dwellings are thus unlike Neoeskimo features of a similar nature, which have clearly defined sleeping areas (see e.g., Birket-Smith, 1929:86; Boas, 1964:141, 145; Savelle, 1987b). The most likely defined sleeping areas are in tent rings with midpassages. It has often been suggested that the midpassage represents the area used for cooking, domestic, and tool manufacturing activities, while the adjacent areas on either side represent living and sleeping areas (e.g., McGhee, 1996:40, 133; LeMoine, 2003). This is not to suggest that sleeping and the other activities did not overlap in these adjacent areas, but that these areas are proportionate to the number of occupants. Thus, in cases where mid-passages run the entire length of the feature, probable sleeping areas can be determined. However, in cases with midpassages that do not extend the entire length of the structure (see e.g., Knuth, 1967; Andreason, 2003; Damkjar, 2003; Jensen, 2005), total sleeping area is more difficult to estimate, and in the case of isolated midpassages, simple tent rings, tent rings with small hearths, and small paved areas, such an estimate is very problematic.

One way to address this issue, at least for the tent rings and isolated midpassages, is to a) first determine a conversion rate to estimate the probable original feature size for midpassages without tent rings, and then b) compare these estimated sizes with overall sizes of tent rings with midpassages and tent rings lacking midpassages. This is an admittedly experimental and heuristic approach, but it should provide insights into potential differences in activity vs. sleeping areas between the different feature types.

The clearest dwelling outline is that of the tent ring, which is typically oval to rectangular. Tables 6 and 7 give summary statistics of tent ring dimensions and dimensions of dwelling features with midpassages, and Figure 10 illustrates the range of floor areas in both types of dwellings. On the Kent Peninsula, the average tent ring size is $8.5 \mathrm{~m}^{2}$ and the average midpassage dwelling is $8.4 \mathrm{~m}^{2}$. On King William Island, average dwelling sizes are larger $\left(10.8 \mathrm{~m}^{2}\right.$ 
for tent rings and $12.3 \mathrm{~m}^{2}$ for midpassage dwelling). In both cases, the differences between the means are significant at the $95 \%$ confidence level $(z=2.66$ for tent rings; $\mathrm{z}=3.14$ for midpassages; $\mathrm{z}_{0.005}=2.576$ ). On the Kent Peninsula, the largest tent ring encountered was $29.1 \mathrm{~m}^{2}$, but tent rings larger than $20 \mathrm{~m}^{2}$ are rare and tent rings larger than $10 \mathrm{~m}^{2}$ are uncommon. The largest midpassage dwelling encountered on the Kent Peninsula was $22.9 \mathrm{~m}^{2}$, but again midpassage dwellings larger than $20 \mathrm{~m}^{2}$ are rare, and those larger than $10 \mathrm{~m}^{2}$ are uncommon. On King William Island, the largest midpassage dwelling encountered was $57.97 \mathrm{~m}^{2}$ (described above under Uncommon Dwelling Features), which is somewhat larger that the largest dwelling recorded on western Boothia Peninsula. Here again, midpassage dwellings larger than $20 \mathrm{~m}^{2}$ are rare. On King William Island, in contrast to the Kent Peninsula, but like the Boothia Peninsula, midpassage dwellings with floor areas between 10 and $20 \mathrm{~m}^{2}$ are common.

However, perhaps first, at least from average to larger dwellings, one should subtract the area of the floor used for non-sleeping purposes. In dwellings with clear midpassages, the midpassage presumably represents the cooking, food preparation, and internal storage area, and the rest of the dwelling is the area available for sleeping. In simple tent rings lacking internal structures, however, the entire floor area may have been used for sleeping, and parts of it were used otherwise when people were not sleeping. Although this floor use would differ from that of ethnographically documented mobile Inuit groups in the Canadian Arctic, who typically used approximately half of the dwelling area for sleeping purposes (see e.g., Birket-Smith, 1929:86; Boas, 1964:141, 145; Savelle, 1987b), we did not observe any clear structural divisions (aside from the midpassages and associated hearths already mentioned) that might separate sleeping from other domestic activities in Paleoeskimo tent rings. If we assume that the smallest dwellings accommodated one or two adults, the dwelling peaks of 6-10 $\mathrm{m}^{2}$ may represent the average nuclear family of four to five people. Dwellings between 10 and $20 \mathrm{~m}^{2}$ presumably represent extended families or other kin groups.

Paleoeskimo paved areas (average $4.6 \mathrm{~m}^{2}$, maximum $8.6 \mathrm{~m}^{2}$, Kent Peninsula; average $5.1 \mathrm{~m}^{2}$, maximum $14.6 \mathrm{~m}^{2}$, King William Island) are systematically smaller than tent rings (see Savelle and Dyke [in press] for Boothia Peninsula data), and hence they probably represent only partial dwelling floor areas. Some may be particularly disturbed midpassages. Nevertheless, their size frequency distributions indicate a predominance of nuclear families of a size comparable to those indicated by the dwellings with clearer perimeters.

When feature area is considered in the context of elevation (Fig. 11), no strong patterns emerge, because the range of feature sizes changes little through time in either region. The remarkable feature of the distributions is the consistently smaller average size of dwellings on the Kent Peninsula, which presumably indicates smaller average family size. Fifth-order polynomial regressions of the data suggest
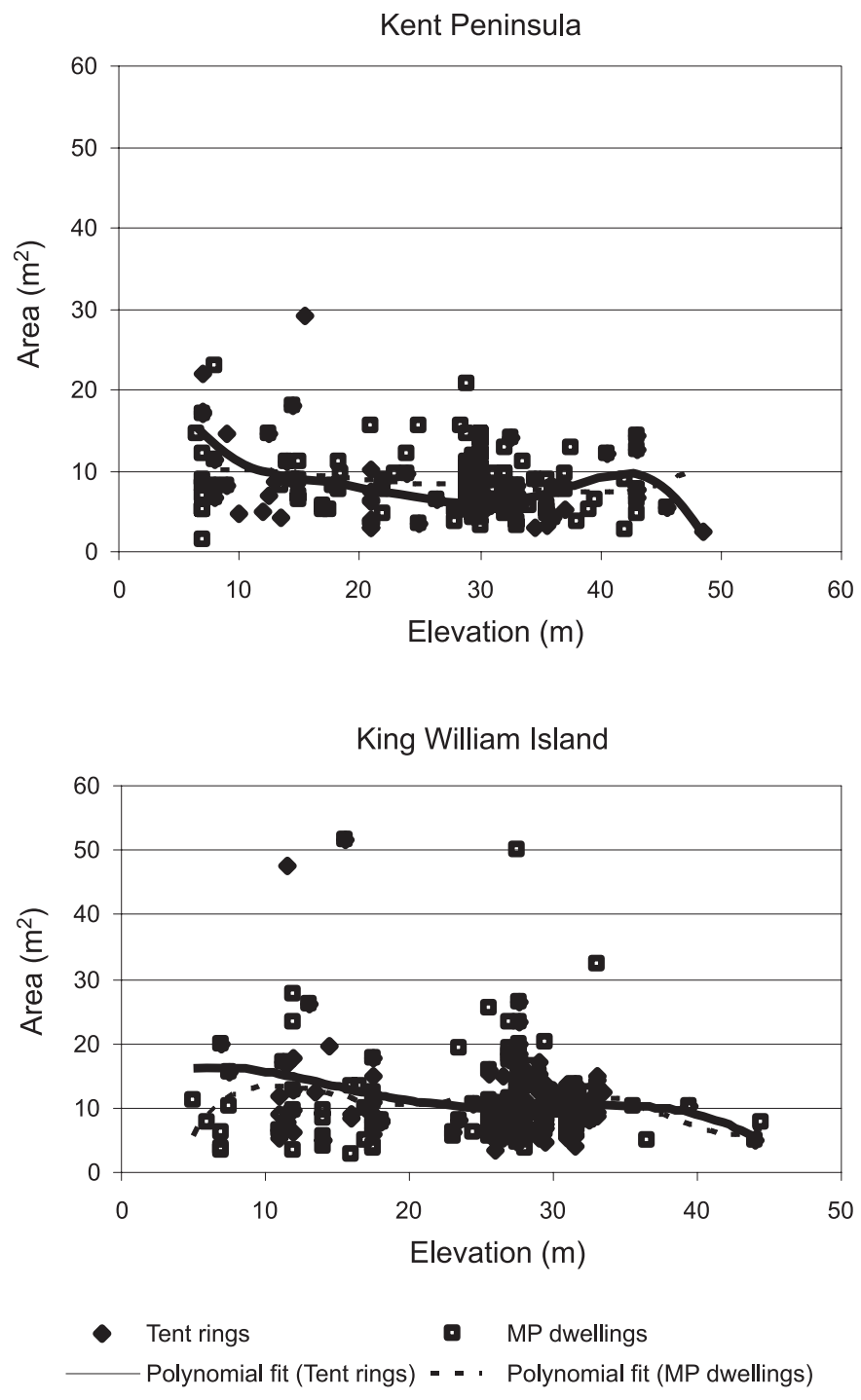

FIG. 11. Area-elevation scatter plots of dwelling features on Kent Peninsula and King William Island. Note different $\mathrm{X}$-axis scales.

a slight tendency for increasing tent ring sizes below $30 \mathrm{~m}$ on both the Kent Peninsula and King William Island. However, that trend is only weakly, or is not at all, supported by the regression lines for midpassage dwellings on the Kent Peninsula. Some of the conspicuously oversized outliers seen on these plots, such as the $57.97 \mathrm{~m}^{2}$ Dorset feature at $12 \mathrm{~m}$ on King William Island, were discussed above. The $47.5 \mathrm{~m}^{2}$ tent ring at $11.5 \mathrm{~m}$ on King William Island (site 06-194-F1; NjLg-35) is undated, as are the two other features at that site. However, its elevation indicates that its maximum age is late Pre-Dorset. The $50.1 \mathrm{~m}^{2}$ midpassage dwelling at $27.5 \mathrm{~m}$ on King William Island is dated on Salix charcoal to $4110 \pm 15$ BP (UCIAMS-30372), thus demonstrating occasional - in our experience rare-use of large dwellings, presumably extended family or multifamily dwellings, early in Pre-Dorset time. If $6-10 \mathrm{~m}^{2}$ dwellings represent nuclear family units of four to five people, then these very large features may have been occupied by $30-40$ individuals. As suggested above, these features may 
represent precursors of Late Dorset longhouses. Late Dorset longhouse size (length) has been correlated with aggregation size elsewhere (Damkjar, 2000). The $29.1 \mathrm{~m}^{2}$ tent ring at $15.5 \mathrm{~m}$ on the Kent Peninsula (site 06-86; NfNf-23), the largest single feature there, would not appear as an outlier on King William Island. Although this tent ring is undated, its elevation places it in Early Dorset time at the earliest. We interpreted very large features at small Dorset sites on western Boothia Peninsula as representing the equivalent of the large groupings of small features at higher (Pre-Dorset) elevations: that is, as band aggregations (Savelle and Dyke, in press).

Cumulative dwelling floor area by elevation class is here calculated as the sum of the areas of tent rings and midpassage dwellings. To that value is added the average tent ring area (for each region) for each dwelling site represented by an isolated hearth or a paved area. Because there are no strong changes in mean dwelling size through time (Fig. 11), the patterns of cumulative dwelling areas (Fig. 12) simply mimic those of numbers of dwellings by elevation (Fig. 3). But the cumulative patterns provide an additional index of Paleo-population levels that may at some time be converted to actual populations. They also demonstrate that the oversized dwellings, mainly of Dorset age, do not distort the simple dwelling frequency data as a reflection of occupation levels.

Finally, the question of local or regional population size, while of interest, can be dealt with here only in general terms. We are not aware of any archaeological study, local or regional, in which maximal band-level Paleoeskimo populations have been determined. Accordingly, again we must depend on ethnographic analogy and related studies. In this regard, Wobst (1974), on the basis of computer simulations, suggested that the minimal size of a viable breeding human population ranged between 175 and 475 individuals. The latter figure compares well with total populations of known mobile Inuit groups: the Netsilik were historically estimated at 450-500 individuals (Damas, 1969), the Igloolik at 500550 (Damas, 1969), the Caribou at 430-500 (Birket-Smith, 1929), and the Copper at 800 (Jenness, 1922). In the context of the present study, we can therefore suggest that our peak early Pre-Dorset populations probably represent regional populations of 500 or more individuals, while the moderate Late Pre-Dorset and Late Dorset recoveries following the sharp declines may represent regional populations closer to Wobst's minimum of 175 , and thus were biologically highly susceptible to extinction. Note that we are not suggesting that all populations in our study regions were necessarily members of the same regional groups, but following Sutherland's (1996) suggestion, that they may have been parts of regional groups occupying territories of similar size to those of historic Inuit groups. Thus the King William Island groups may have been members of a much larger King William Island-Boothia Peninsula group similar to the Netsilik Inuit, while the Kent Peninsula group may have been members of a much larger Victoria Island-central Arctic mainland coast group similar to the Copper Inuit.
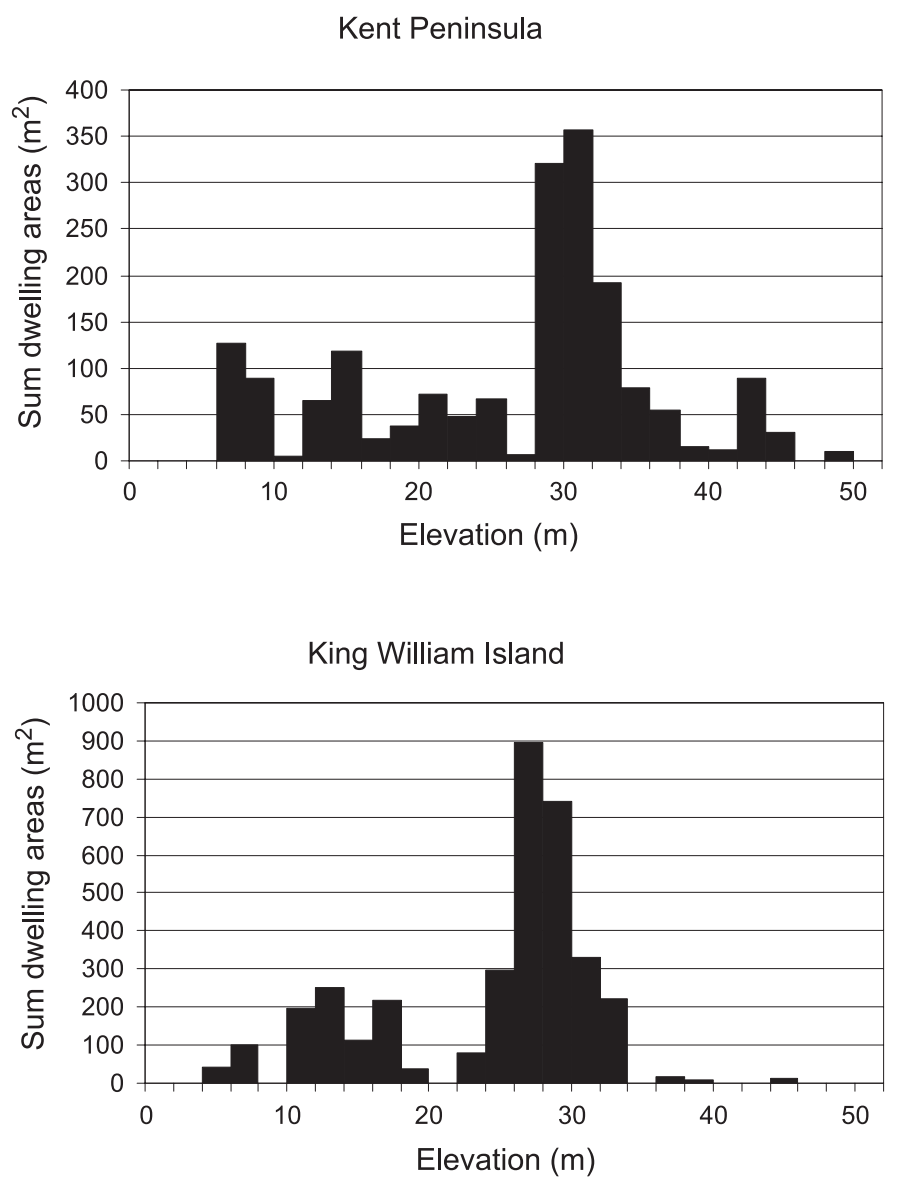

FIG. 12. Cumulative floor areas $\left(\mathrm{m}^{2}\right)$ by elevation, Kent Peninsula and King William Island. Note different y-axis scales.

\section{Paleoeskimo Boom-and-Bust}

Both regions reported on here clearly saw their largest Paleoeskimo populations early in the Pre-Dorset period, specifically 4400 to 3400 , and mainly $4400-3700,{ }^{14} \mathrm{C}$ years ago, if the most secure dates are used. About $66 \%$ of all documented Paleoeskimo dwelling features on the Kent Peninsula and about $74 \%$ of features on King William Island (Fig. 3) were occupied in early Pre-Dorset time. Subsequent population recoveries during late Pre-Dorset and Dorset time were weak in comparison. A decline of the Pre-Dorset population in Arctic Canada in general at about $3700-3600{ }^{14} \mathrm{C}$ years ago has been discussed for some time (e.g., McGhee, 1972), but there are still few measurements or indices of the size or abruptness of the decline. We documented a dramatic population crash of almost identical proportion and timing on western Boothia Peninsula (Savelle and Dyke, in press), east of King William Island, as well as on southwestern Victoria Island (Savelle and Dyke, 2002), about $400 \mathrm{~km}$ west of our Kent Peninsula sites, using the same paleodemographic approach. Hence, the boom-andbust cycle of the early Paleoeskimo seems to have been a nearly synchronous, possibly a truly synchronous, event from the western through to at least the central part of the Northwest Passage. Schledermann (1978) may have 
documented the same, or a similar, event in the CornwallisBathurst Island region, about $500 \mathrm{~km}$ north of the Boothia Peninsula. He plotted frequency of dwellings by elevation and showed peak abundance on raised beach levels that are probably of early Pre-Dorset age.

We recently reviewed suggestions that have been advanced to explain these reductions in Paleoeskimo populations (Savelle and Dyke, in press). Briefly, they include the inevitability of die-offs of hunter-gatherer bands in peripheral environments (McGhee, 1976), over-exploitation of critical food resources (McCartney and Helmer, 1989), and climate forcing of food resource availability (Dekin, 1972; Fitzhugh, 1976; Schledermann, 1978, 1990; Maxwell, 1985; Dumond, 1987; Sutherland, 1992; McGhee, 1996). In order to choose amongst these possibilities, it will be necessary to marshall a good array of paleoenvironmental data of sufficient resolution from both terrestrial and marine environments within the region. Despite recent advances in paleoclimate reconstructions based on pollen stratigraphy (e.g., Zabenskie and Gajewski, 2007; Peros and Gajewski, 2008), it is not possible at this time to choose between climate forcing and resource over-exploitation as the primary cause of the Paleoeskimo crash that occurred around 3700$3600 \mathrm{BP}$.

Seeking relationships between the boom-and-bust cycles described herein and population pulses from the so-called Paleoeskimo "core area," as originally proposed by Maxwell (1976) and McGhee (1976), is premature. Our earliest and most dramatic peaks pre-date the oldest securely dated Paleoeskimo sites in the core area (Foxe Basin and vicinity). This pattern may be the expected consequence of the west-to-east initial Paleoeskimo expansion. But it just as likely results from the fact that the major known PreDorset sites in Foxe Basin (Igloolik and Jens Munk) are too low to record earliest Paleoeskimo times (Savelle et al., in press). However, as noted above, our data indicate consistent and essentially contemporaneous boom-and-bust cycles throughout our own survey regions: Victoria Island (Savelle and Dyke, 2002), the Kent Peninsula and King William Island (this paper), western Boothia Peninsula (Savelle and Dyke, in press), and Somerset Island and eastern Boothia Peninsula (Savelle and Dyke, unpubl. data). Whether the "boom" cycles subsequent to the first one resulted from immigration from a core area or simply represent recovery of local "bust" populations cannot be determined from the sort of data we present until further regional surveys are reported. Furthermore, our understanding of Paleoeskimo occupation of the core area has changed considerably since Meldgaard's original work (see e.g., Bielawski, 1988; Rowley and Rowley, 1997). Most significantly, Paleoeskimo populations appear to have suffered boom-and-bust cycles in the core area as well (Savelle et al., in press), but whether these cycles were synchronous across the Foxe Basin region remains unknown.

\section{CONCLUSIONS}

The central Northwest Passage region, particularly the part around M'Clintock Channel, occupies the harshest environmental zone in the path of Paleoeskimo colonization from the western to the eastern North American Arctic. Nevertheless, early Paleoeskimo dwelling features are abundant there. Paleoeskimo occupation throughout the broader region from western Victoria Island through to at least western Boothia Peninsula went through a series of boom-and-bust cycles. These began with a period of rapidly growing and large populations between about 4500 and $3600{ }^{14} \mathrm{C}$ years $\mathrm{BP}$, following first occupation of the area, which was followed by a dramatic crash. A slight recovery approximately $3100-2500{ }^{14} \mathrm{C}$ years $\mathrm{BP}$ was followed by a second decline, and a final recovery in Late Dorset time was followed by the disappearance of the Paleoeskimo. Small groups of Dorset people lingered on King William Island until about $800{ }^{14} \mathrm{C}$ years $\mathrm{BP}$, and possibly later. Currently available paleoclimate data do not indicate any regionally consistent pattern between climate changes and these boom-and-bust cycles. Thus, a second possibility is that these cycles may relate to repeated episodes of overharvesting of local resources.

Paleoeskimo seasonal patterns here, as in adjacent regions, appear to have been ones in which nuclear or small extended families were dispersed for much of the year, aggregating annually in groups of about 100 or more individuals. Minimal social units do not appear to have changed during seasonal aggregations in Pre-Dorset times. By Dorset times, however, there is some evidence, though not as clear as that on western Boothia Peninsula, that families melded together to form one or a few larger social units living in larger dwellings. Average dwelling sizes on the Kent Peninsula were persistently smaller than on King William Island throughout the Paleoeskimo sequence. The cause of that difference is not evident, because it is the opposite of what might be expected from modern environmental differences.

\section{ACKNOWLEDGEMENTS}

Our work was supported by a Social Sciences and Humanities Research Council grant and by the Geological Survey of Canada (GSC) Climate Change Programme. Arctic logistics were provided by Polar Continental Shelf Project of Natural Resources Canada. We are grateful to Melanie Poupart for GIS and graphics support, to John Southon (University of California at Irvine) for radiocarbon dating, to Bob Mott (GSC) for wood and charcoal identifications, and to Linda Ley (Canadian Museum of Nature) for moss identifications. Internal review at the GSC by Rod Smith helped improve manuscript clarity, and insightful comments by three anonymous referees resulted in our expanding on, and clarifying, a number of issues. 


\section{REFERENCES}

Amundsen, R. 1908. The Northwest Passage. London: Archibald Constable.

Andreasen, C. 2003. Paleoeskimo dwellings in Greenland: A survey. Études/Inuit/Studies 27:283-308.

Balikci, A. 1984. Netsilik. In: Damas, D., ed. Handbook of North American Indians, Vol. 5: Arctic. Washington, D.C.: Smithsonian Institution. 415-430.

Barber, D.G., and Iacozza, J. 2004. Historical analysis of sea ice conditions in M'Clintock Channel and the Gulf of Boothia, Nunavut: Implications for ringed seal and polar bear habitat. Arctic 57:1-14.

Barr, W. 1991. Back from the brink: The road to muskox conservation in the Northwest Territories. Calgary: The Arctic Institute of North America, University of Calgary.

Bielawski, E. 1988. Paleoeskimo variability: The early Arctic Small-Tool tradition in the central Canadian Arctic. American Antiquity 53:52-74.

Binford, L.R. 1980. Willow smoke and dogs' tails: Huntergatherer settlement systems and archaeological site formation. American Antiquity 45:4-20.

-1982. The archaeology of place. Journal of Anthropological Archaeology 1:5-31.

Birket-Smith, K. 1929. The Caribou Eskimos. Report of the Fifth Thule Expedition 1921-24, Vol. 5. Copenhagen: Gyldendal.

Blake, W., Jr. 1963. Notes on glacial geology, northeastern District of Mackenzie. GSC Paper 63-28. Ottawa: Geological Survey of Canada. 12 p.

Boas, F. 1964. The Central Eskimo. Lincoln: University of Nebraska Press.

Brice-Bennett, C. 1976. Inuit land use in the east-central Canadian Arctic. Inuit Land Use and Occupancy Project, Vol. 1: Land use and occupancy. Ottawa: Department of Indian and Northern Affairs. 63-82.

Craig, B.G. 1964. Surficial geology of Boothia Peninsula and Somerset, King William, and Prince of Wales islands, District of Franklin. GSC Paper 63-44. Ottawa: Geological Survey of Canada. $10 \mathrm{p}$.

Damas, D. 1969. Characteristics of Central Eskimo band structure. In: Damas, D., ed. Contributions to anthropology: Band societies 228. Ottawa: National Museum of Canada. 116-134.

- 1984. Copper Eskimo. In: Damas, D., ed. Handbook of North American Indians, Vol. 5: Arctic. Washington, D.C.: Smithsonian Institution. 397-414.

Damkjar, E. 2000. A survey of Late Dorset longhouses. In: Appelt, M., Berglund, J., and Gullov, H.C., eds. Identities and cultural contrasts in the Arctic. Danish Polar Center Publication 8. Copenhagen: Danish National Museum and Danish Polar Center. $170-180$.

- 2003. Transitional occupations of southeastern Somerset Island, Nunavut. Études/Inuit/Studies 27:213-238.

Dekin, A.A., Jr. 1972. Climatic change and cultural change: A correlative study from Eastern Arctic prehistory. Polar Notes 12:11-31.

Dumond, D.E. 1987. The Eskimos and Aleuts. London: Thames and Hudson.
Dyke, A.S., and Dredge, L.A. 1989. Quaternary geology of the northwestern Canadian Shield. In: Fulton, R.J., ed. Quaternary geology of Canada and Greenland, Geology of Canada No. 1. Ottawa: Geological Survey of Canada. 189-214.

Dyke, A.S., Morris, T.F., and Green, D.E.C. 1991. Postglacial tectonic and sea level history of the Central Canadian Arctic. GSC Bulletin 397. Ottawa: Geological Survey of Canada.

Dyke, A.S., Dale, J.E., and McNeely, R. 1996a. Marine molluscs as indicators of environmental change in glaciated North America and Greenland during the last 18000 years. Géographie physique et Quaternaire 50:125-184.

Dyke, A.S., Hooper, J., and Savelle, J.M. 1996b. A history of sea ice in the Canadian Arctic Archipelago based on postglacial remains of the bowhead whale (Balaena mysticetus). Arctic 49:235-255.

Dyke, A.S., McNeely, R.N., and Hooper, J. 1996c. Marine reservoir corrections for bowhead whale radiocarbon age determinations. Canadian Journal of Earth Sciences 33:1628-1637.

Dyke, A.S., Dredge, L.A., and Hodgson, D.A. 2005. North American deglacial marine- and lake-limit surfaces. Géographie physique et Quaternaire 59:155-185.

Edlund, S.A. 1986. Modern Arctic vegetation distribution and its congruence with summer climate patterns. Proceedings: Impact of Climate Change on the Canadian Arctic. A Canadian Climate Change Program Workshop. Orillia, Ontario: Environment Canada. 84-98.

Environment Canada. 2008. Canadian climate normals or averages 1971-2000. National Climate Data and Information Archive. http://www.climate.weatheroffice.ec.gc.ca/climate_normals.

Farquharson, D.R. 1976. Inuit land use in the west-central Canadian Arctic. Inuit Land Use and Occupancy Project, Vol. 1: Land use and occupancy. Ottawa: Department of Indian and Northern Affairs. 33-61.

Fitzhugh, W. 1976. Environmental factors in the evolution of Dorset Culture: A marginal proposal for Hudson Bay. In: Maxwell, M., ed. Eastern Arctic prehistory: Paleoeskimo problems. Memoirs for the Society of American Archaeology 31. $139-149$.

Friesen, T.M. 2004. Contemporaneity of Dorset and Thule cultures in the North American Arctic: New radiocarbon dates from Victoria Island, Nunavut. Current Anthropology 45:685-691.

Gunn, A., Shank, C., and McLean, B. 1991. The history, status and management of muskoxen on Banks Island. Arctic 44: $188-195$.

Heard, D.C. 1992. Distribution and abundance of caribou and muskoxen on north-west Victoria Island. Manuscript report available at the Department of Environment and Natural Resources, 600, 5102-50th Avenue, Yellowknife, Northwest Territories X1A 3S8.

Hélie, R.G. 1985. Surficial geology, King William Island and Adelaide Peninsula, Districts of Keewatin and Franklin. Map 1618A, scale 1:250000. Ottawa: Geological Survey of Canada.

Hofman, J.L., and Enloe, J.G. 1992. Piecing together the past: Applications of refitting studies in archaeology. Oxford: BAR International Series 578, Tempvs Reparatvm. 
Jenness, D. 1922. The life of the Copper Eskimo. Ottawa: Report of the Canadian Arctic Expedition, 1913-1918, Vol. 12.

Jensen, J.F. 2005. Paleoeskimo continuity and discontinuity in West Greenland. In: Sutherland, P.D., ed. Contributions to the study of the Dorset Palaeoeskimos. Mercury Series, Archaeology Paper 167. Ottawa: Canadian Museum of Civilization. 93-104.

Kelly, R.L. 1983. Hunter-gatherer mobility strategies. Journal of Anthropological Research 39:277-306.

- 1995. The foraging spectrum: Diversity in hunter-gatherer lifeways. Washington, D.C.: Smithsonian Institution Press.

Kerr, D.E. 1996. Late Quaternary sea-level history in the Paulatuk to Bathurst Inlet area, Northwest Territories. Canadian Journal of Earth Sciences 33:389-403.

Knuth, E. 1967. Archaeology of the musk-ox way. Paris: École Pratique des Hautes Études, Sorbonne.

LeBlanc, S., Nagy, M., and de Lizaraga, R., eds. 2003. Paleoeskimo architecture. Études/Inuit/Studies 27.

LeMoine, G. 2003. Woman of the house: Gender, architecture and ideology in Dorset prehistory. Arctic Anthropology 40: $121-138$.

LeMoine, G., Helmer, J., and Grønnow, B. 2003. Late Dorset architecture on Little Cornwallis Island, Nunavut. Études/ Inuit/Studies 27:255-282.

Mathiassen, T. 1927. Archaeology of the Central Eskimos. Report of the Fifth Thule Expedition 1921-24, Vol. 4. Copenhagen: Gyldendal.

Maxwell, M.S. 1976. Introduction. In: Maxwell, M., ed. Eastern Arctic prehistory: Paleoeskimo problems. Memoirs for the Society of American Archaeology 31. 1-5.

- 1985. Prehistory of the eastern Arctic. Orlando: Academic Press.

McCartney, P.H., and Helmer, J.W. 1989. Marine and terrestrial mammals in High Arctic paleoeconomy. Archaeozoologia 3(1/2):143 - 160 .

McClintock, F.L., Sir 1859. The voyage of the Fox in the Arctic seas: A narrative of the discovery of the fate of Sir John Franklin and his companions by Captain M'Clintock. London: J. Murray.

McGhee, R. 1972. Climatic change and the development of Canadian Arctic cultural traditions. In: Vasari, Y., Hyvarinnen, H., and Hicks, S., eds. Climatic changes in Arctic areas during the last ten thousand years. Acta Universitatis Ouluensis, Scientificae Rerum, Geologica 1:39-60.

- 1976. Paleoeskimo occupations of central and High Arctic Canada. In: Maxwell, M., ed. Eastern Arctic prehistory: Paleoeskimo problems. Memoirs for the Society of American Archaeology 31. 15-39.

- 1996. Ancient people of the Arctic. Vancouver: UBC Press.

McNeely, R., Dyke, A.S., and Southon, J.R. 2006. Canadian marine reservoir ages: Preliminary data assessment. GSC Open File 5049, CD-ROM. Ottawa: Geological Survey of Canada.

Nunavut Wildlife Management Board. 2002. Minutes: Meeting No. 34. Iqaluit, 10-12 December. Iqaluit: Department of Renewable Resources.
Peros, M.C., and Gajewski, K. 2008. Holocene climate and vegetation change on Victoria Island, western Canadian Arctic. Quaternary Science Reviews 27:235-249.

Rasmussen, K. 1931. The Netsilik Eskimos. Report of the Fifth Thule Expedition, Vol. 8. Copenhagen: Gyldendal.

Ross, J. 1835. Narrative of a second voyage in search of a Northwest Passage; and of a residence in the Arctic regions during the years 1829, 1830, 1831, 1832, 1833. London: A.W. Webster.

Rowley, G., and Rowley, S. 1997. Igloolik Island before and after Jorgen Meldgaard. In: Gilberg, R., and Gullov, H., eds. Fifty years of Arctic research: Anthropological studies from Greenland to Siberia. Copenhagen: National Museum of Denmark. 269-276.

Ryan, K. 2003. An overview of Palaeoeskimo architectural remains in the central Canadian Low Arctic. Études/Inuit/ Studies 27:29-66.

Savelle, J.M. 1987a. Collectors and foragers: Subsistencesettlement system change in the central Canadian Arctic, A.D. 1000-1960. Oxford: BAR International Series 358, Tempvs Reparatvm.

- 1987b. The archaeology of a Netsilik Inuit camp depicted by John Ross in 1831. Polar Record 23(145):427-436.

Savelle, J.M., and Dyke, A.S. 2002. Variability in Palaeoeskimo occupation on southwestern Victoria Island, Arctic Canada. World Archaeology 33:508-522.

2007. Preliminary report of archaeological investigations on Kent Peninsula and King William Island, Nunavut. Department of Culture, Language, Elders and Youth, Government of Nunavut, Box 310, Igloolik, Nunavut X0A 0L0.

- In press. Paleoeskimo demography on western Boothia Peninsula, central Canadian Arctic. Journal of Field Archaeology.

Savelle, J.M., Dyke, A.S., and Poupart, M. In press. Paleo-Eskimo occupation history of Foxe Basin, Nunavut: Implications for the "core area." In: Maschner, H., Mason, O., and McGhee, R., eds. The Northern World AD 900-1400: The dynamics of climate, economy, and politics in hemispheric perspective. Salt Lake City: University of Utah Press.

Schledermann, P. 1978. Prehistoric demographic trends in the Canadian High Arctic. Canadian Journal of Archaeology $2: 43-58$.

- 1990. Crossroads to Greenland: 3000 years of prehistory in the eastern High Arctic. Calgary: The Arctic Institute of North America, University of Calgary.

Stewart, H. 2006. The fish tale that is never told: A reconsideration of the importance of fish in Inuit societies. In: Kishigami, N., and Savelle, J.M., eds. Indigenous use and management of marine resources. Senri Ethnological Studies 67. 345-361.

Stockpole, E.A. 1965. The long Arctic search: The narrative of Lieutenant Frederick Schwatka, U.S.A. 1878-1880, seeking the records of the lost Franklin expedition. Mystic, Connecticut: Marine Historical Association, Inc.

Stuiver, M., Reimer, P.J., Bard, E., Beck, J.W., Burr, G.S., Hugen, K.A., Kromer, B., McCormack, G., Van der Plicht, J., and Spurk, M. 1998. INTCAL98 radiocarbon calibration, 24,0000 cal BP. Radiocarbon 40:1041-1084. 
Sutherland, P.D. 1992. Environmental change and prehistory in Arctic Canada. In: Woo, M.-K., and Gregor, D.J., eds. Arctic environment: Past, present and future. Hamilton, Ontario: Department of Geography, McMaster University. 139-153.

- 1996. Continuity and change in the Paleoeskimo prehistory of northern Ellesmere Island. In: Grønnow, B., and Pind, J., eds. The Paleoeskimo cultures of Greenland: New perspectives in Greenlandic archaeology. DPC Publication 1. Copenhagen: Danish Polar Center. 271-294.

- 2003. Variability and change in Palaeo-Eskimo architecture: A view from the Canadian High Arctic. Études Inuit Studies 27:191-212.
Taylor, W.E. 1972. An archaeological survey between Cape Parry and Cambridge Bay, N.W.T. Mercury Series, Paper 1. Ottawa: Archaeological Survey of Canada.

Waguespack, N.M. 2002. Caribou sharing and storage: Refitting the Palanga site. Journal of Anthropological Archaeology 21:396-417.

Wobst, H.M. 1974. Boundary conditions for Paleolithic social systems: A simulation approach. American Antiquity 39: $147-178$.

Zabenskie, S., and Gajewski, K. 2007. Post-glacial climatic change on Boothia Peninsula, Nunavut, Canada. Quaternary Research 68:261-270. 